\title{
Cretaceous-Paleogene plant extinction and recovery in Patagonia
}

\author{
Elena Stiles (D), Peter Wilf, Ari Iglesias, María A. Gandolfo, and N. Rubén Cúneo
}

\begin{abstract}
The Cretaceous-Paleogene (K/Pg) extinction appears to have been geographically heterogeneous for some organismal groups. Southern Hemisphere $\mathrm{K} / \mathrm{Pg}$ palynological records have shown lower extinction and faster recovery than in the Northern Hemisphere, but no comparable, well-constrained Southern Hemisphere macrofloras spanning this interval had been available. Here, macrofloral turnover patterns are addressed for the first time in the Southern Hemisphere, using more than 3500 dicot leaves from the latest Cretaceous (Maastrichtian) and the earliest Paleocene (Danian) of Argentine Patagonia. A maximum ca. 90\% macrofloral extinction and ca. 45\% drop in rarefied species richness is estimated across the $\mathrm{K} / \mathrm{Pg}$, consistent with substantial species-level extinction and previously observed extirpation of host-specialized leaf mines. However, prior palynological and taxonomic studies indicate low turnover of higher taxa and persistence of general floral composition in the same sections. High species extinction, decreased species richness, and homogeneous Danian macrofloras across time and facies resemble patterns often observed in North America, but there are several notable differences. When compared with boundary-spanning macrofloras at similar absolute paleolatitudes $\left(\mathrm{ca} .50^{\circ} \mathrm{S}\right.$ or $50^{\circ} \mathrm{N}$ ) from the Williston Basin (WB) in the Dakotas, both Maastrichtian and Danian Patagonian species richnesses are higher, extending a history of elevated South American diversity into the Maastrichtian. Despite high species turnover, our analyses also reveal continuity and expansion of leaf morphospace, including an increase in lobed and toothed species unlike the Danian WB. Thus, both Patagonian and WB K/Pg macrofloras support a significant extinction event, but they may also reflect geographically heterogeneous diversity, extinction, and recovery patterns warranting future study.
\end{abstract}

Elena Stiles. *Department of Geosciences, Pennsylvania State University, University Park, Pennsylvania 16802, U.S.A. E-mail: estiles@uw.edu. *Present address: Department of Biology, University of Washington, Seattle, Washington 98105, U.S.A.

Peter Wilf. Department of Geosciences, Pennsylvania State University, University Park, Pennsylvania 16802, U.S.A. E-mail: pwilf@psu.edu

Ari Iglesias. Consejo Nacional de Investigaciones Científicas y Técnicas (CONICET)-Universidad Nacional del Comahue INIBIOMA, San Carlos de Bariloche 8400, Río Negro, Argentina. E-mail:ari_iglesias@yahoo.com.ar

María Alejandra Gandolfo. L.H. Bailey Hortorium, Plant Biology Section, School of Integrative Plant Science,

Cornell University, Ithaca, New York 14853, U.S.A. E-mail: mag4@cornell.edu

N. Rubén Cúneo. Consejo Nacional de Investigaciones Científicas y Técnicas (CONICET)-Museo Paleontológico Egidio Feruglio, Avenida Fontana 140, Trelew 9100, Chubut, Argentina. E-mail: rcuneo@mef.org.ar

Accepted: 27 August 2020

Data available from the Dryad Digital Repository: https://doi.org/10.5061/dryad.jsxksn071

\section{Introduction}

The devastating environmental consequences of the end-Cretaceous bolide impact affected both marine and terrestrial organisms (e.g., Alvarez et al. 1980; Prinn and Fegley 1987; Robertson et al. 2013; Vellekoop et al. 2014; Tyrrell et al. 2015; Artemieva and Morgan 2017; Brugger et al. 2017). Over $60 \%$ of Cretaceous species became extinct, making the Cretaceous-Paleogene $(\mathrm{K} / \mathrm{Pg})$ event the most recent of the "big five" mass extinctions (Raup and Sepkoski 1982; Jablonski 2005; Schulte et al. 2010). Although the $\mathrm{K} / \mathrm{Pg}$ event affected biotas globally, the severity of the extinction and the pacing of the recovery were geographically heterogeneous for some groups of organisms (see next paragraph). Modern biodiversity is shaped by the surviving lineages of the $\mathrm{K} / \mathrm{Pg}$ (e.g., Erwin 2002; Krug et al. 2017), establishing today's biogeographic patterns, in part, as the legacy of a globally heterogeneous extinction (e.g., Wolfe 1987).

Southern Hemisphere records of calcareous nannoplankton, insect herbivory, and terrestrial

(C) The Author(s), 2020. Published by Cambridge University Press on behalf of The Paleontological Society. This is an Open Access article, distributed under the terms of the Creative Commons Attribution licence (http://creativecommons.org/ licenses/by /4.0/), which permits unrestricted re-use, distribution, and reproduction in any medium, provided the $\sim \cdots: \sim \sim n-1$ 
palynomorphs indicate lower extinction and/ or faster recoveries than Northern Hemisphere counterparts (Vajda et al. 2001; Vajda and Raine 2003; Iglesias et al. 2007; Pole and Vajda 2009; Jiang et al. 2010; Barreda et al. 2012; Cantrill and Poole 2012; Schueth et al. 2015; Donovan et al. 2016). Furthermore, several plant and vertebrate groups that had been known only from Mesozoic localities in the Northern Hemisphere, have been reported in Cenozoic Southern Hemisphere deposits suggesting that they survived the $\mathrm{K} / \mathrm{Pg}$ in southern latitudes (Case and Woodburne 1986; Pascual et al. 1992; Bonaparte et al. 1993; Goin et al. 2006, 2012; McLoughlin et al. 2008, 2011; Gelfo et al. 2009; Sterli and de la Fuente 2019). Proposed explanations for this geographic heterogeneity (Jiang et al. 2010; Donovan et al. 2016, 2018) have referenced increased distance from the Mexican impact site (Schulte et al. 2010), oceanic buffering of impact winter temperatures in the Southern Hemisphere (Bardeen et al. 2017; Tabor et al. 2020), and a bolide impact angle that would have directed most ejecta and debris northward (Schultz and D'Hondt 1996).

Because plants are the primary producers in terrestrial ecosystems and one of the most biodiverse groups of organisms, the paleobotanical record is critical for understanding extinction events on land (e.g., Nichols and Johnson 2008). However, the vast majority of plant-bearing $\mathrm{K} / \mathrm{Pg}$ continental sites is concentrated in the western interior of North America (NAM), which bears numerous examples of stratigraphically and temporally well constrained boundary-spanning palynofloras (e.g., Nichols et al. 1986; Nichols and Fleming 1990; Sweet et al. 1990, 1999; Sweet and Braman 2001; Nichols 2002; Bercovici et al. 2009) and macrofloras (e.g., Wolfe and Upchurch 1986; Johnson et al. 1989; Johnson and Hickey 1990; Johnson 1992, 2002; Upchurch 1995; Barclay et al. 2003; Nichols and Johnson 2008). Southern Hemisphere $\mathrm{K} / \mathrm{Pg}$-spanning paleofloras are scarce and have been primarily limited to palynological records (e.g., Vajda-Santivanez 1999; Vajda et al. 2001; Vajda and Raine 2003; Pole and Vajda 2009; Barreda et al. 2012; Cantrill and Poole 2012; Scasso et al. 2020). Cretaceous-Paleogene macrofloras from New
Zealand revealed a dramatic floral turnover (Pole and Vajda 2009) and a paleoclimatic cooling trend consistent with global records (Kennedy et al. 2002) across the $\mathrm{K} / \mathrm{Pg}$, but the severity of the macrofloral extinction was not estimated. Until now, no well-constrained and well-sampled macrofloral Maastrichtian and Danian sites from the same region have been available in the Southern Hemisphere.

Recent studies of the latest Cretaceous (Maastrichtian) Lefipán and early Paleocene (Danian) Salamanca and Peñas Coloradas Formations of Chubut, Argentine Patagonia (Fig. 1; and see "Materials" and "Analytical Methods") showed lower palynological extinction, faster recovery of insect herbivory damage-type diversity, and remarkably diverse Danian macrofloras compared with most NAM sections of the same ages. Specifically, spore and pollen records showed $<10 \%$ extinction across the $\mathrm{K} / \mathrm{Pg}$ compared with the $30 \%-40 \%$ extinction in NAM palynofloras (Nichols and Fleming 1990; Sweet and Braman 2001; Hotton 2002; Nichols 2002; Barreda et al. 2012). Notably, in early Danian Patagonian pollen records, an abundance spike of the conifer Classopollis represents the last record of a genus that is otherwise only known until the Late Cretaceous worldwide (Barreda et al. 2012). Insect feeding-damage types on angiosperm leaves recovered to pre-K/Pg diversity levels within about $4 \mathrm{Myr}$, compared with the estimated ca. 9 Myr for NAM (Donovan et al. 2016, 2018), and Danian macrofloras of the Salamanca Formation are much more diverse than most coeval NAM counterparts, suggesting a faster-paced Patagonian recovery (Iglesias et al. 2007). However, comparable Maastrichtian leaf floras from the same Patagonian region have not yet been evaluated using similar methods.

Gymnosperm macrofossils of the Lefipán and Salamanca Formations have been the subject of taxonomic studies (Zamuner et al. 2000; Brea et al. 2005; Quiroga et al. 2015; Ruiz et al. 2017; Wilf et al. 2017; AndruchowColombo et al. 2018, 2019; Escapa et al. 2018), indicating the survival of the Podocarpaceae and Araucariaceae conifer families. The presence of several derived angiosperm groups known from reproductive material in the Salamanca Formation suggests that they also 
represent K/Pg survivor families (Iglesias et al. 2007; Raigemborn et al. 2009; Jud et al. 2017, 2018a,b; Supplementary Tables 1, 2). Angiosperm leaf fossils have sourced the aforementioned work on $\mathrm{K} / \mathrm{Pg}$ insect damage (Donovan et al. 2016, 2018), yet the extensive leaf collections on which the insect herbivory was documented have not been rigorously compared to quantify macrofloral species extinction in Patagonia across the Cretaceous/ Paleogene transition.

Fossil dicot leaves from the Maastrichtian and Danian of Patagonia (Fig. 1) together offer insight into macrofloral K/Pg diversity, and potential extinction and recovery patterns with well-sampled, stratigraphically and temporally constrained collections for the first time in the Southern Hemisphere (Iglesias et al. 2007; Scasso et al. 2012; Clyde et al. 2014; Donovan et al. 2016, 2018). Through the analysis of more than 3500 leaf fossils from four localities, this study addresses terminal Cretaceous and early Paleocene macrofloral diversity in Patagonia, and the possible effects of the $\mathrm{K} / \mathrm{Pg}$ extinction event on the floras of the region while considering the potential climatic, sampling, and ecological biases impacting the observations. Although the main goal of this contribution is to document the first temporally constrained $\mathrm{K} / \mathrm{Pg}$-spanning macrofloral assemblages occurring within the same region in the Southern Hemisphere, we compare our results with the well-sampled, boundary-spanning $\mathrm{K} / \mathrm{Pg}$ NAM macrofloras from similar absolute paleolatitudes (ca. $50^{\circ} \mathrm{N}$ or $50^{\circ} \mathrm{S}$ ) in the Williston Basin (WB) in North Dakota (Johnson 2002; Wilf and Johnson 2004) to further explore potential biases in our observations and to examine potential geographic heterogeneity in macrofloral patterns among two widely separated regions.

\section{Materials}

The collections studied here are primarily the same as those from Chubut, Argentina, used in earlier work on Danian floral diversity (e.g., Iglesias 2007; Iglesias et al. 2007) and $\mathrm{K} / \mathrm{Pg}$ insect damage (Donovan et al. 2016, 2018), plus some additional material previously not cataloged (Supplementary Table 3). Iglesias et al. (2007) documented Danian dicot-leaf diversity by morphotyping and assigning systematic affinities when possible (Iglesias 2007; Iglesias et al. 2007; more recent updates shown in Supplementary Table 1). Donovan et al. $(2016,2018)$ analyzed the insect feedingdamage diversity on the leaves from Maastrichtian and Danian collections and proposed a preliminary morphotype classification for the Maastrichtian leaves. The leaf collections from the Lefipán (Maastrichtian) and Salamanca and Peñas Coloradas (Danian) Formations were compiled over a series of field trips involving the four junior authors and others since 2003, and they are curated in the Paleobotanical Collection of the Museo Paleontológico Egidio Feruglio (MEF; repository acronym MPEF-Pb), Trelew, Argentina (Supplementary Table 3). All collections studied are unbiased, complete census collections of all identifiable material found, taken to the lab at MEF, and vetted and tallied. Although they are separated by ca. $400 \mathrm{~km}$ (Fig. 1), and the $\mathrm{K} / \mathrm{Pg}$ boundary horizon itself is not preserved in the Lefipán or Salamanca Formations, these Maastrichtian and Danian collections represent broadly similar, marginal marine depositional settings and the only large, stratigraphically constrained leaf collections from their time periods sourced from a single region in the Southern Hemisphere. In addition to the summary presentation and citations that follow, further detailed accounts of collecting methods and sites and full descriptions of the leaf morphotypes are in separate preparation.

Lefipán Formation.-The siliciclastic Lefipán Formation conformably overlies the Campanian-Maastrichtian fluvio-estuarine Paso del Sapo Formation, and it is unconformably overlain by the Eocene Barda Colorada Ignimbrite (Spalletti 1996; Aragón and Mazzoni 1997; Scasso et al. 2012; Aragón et al. 2018) and other Paleogene volcanic units (Aragón et al. 2018). Deposited in the shallow, paleo-Atlantic Paso del Sapo embayment (Fig. 1A,B), the Lefipán Formation records the latest Cretaceous (?Campanian-Maastrichtian) to early Paleocene (Danian) infilling of the Jurassicearly Paleocene Cañadón Asfalto Basin (Fig. 1A) (Spalletti 1996; Scasso et al. 2012; Figari et al. 2015). Leaf cuticular $p \mathrm{CO}_{2}$ estimates 

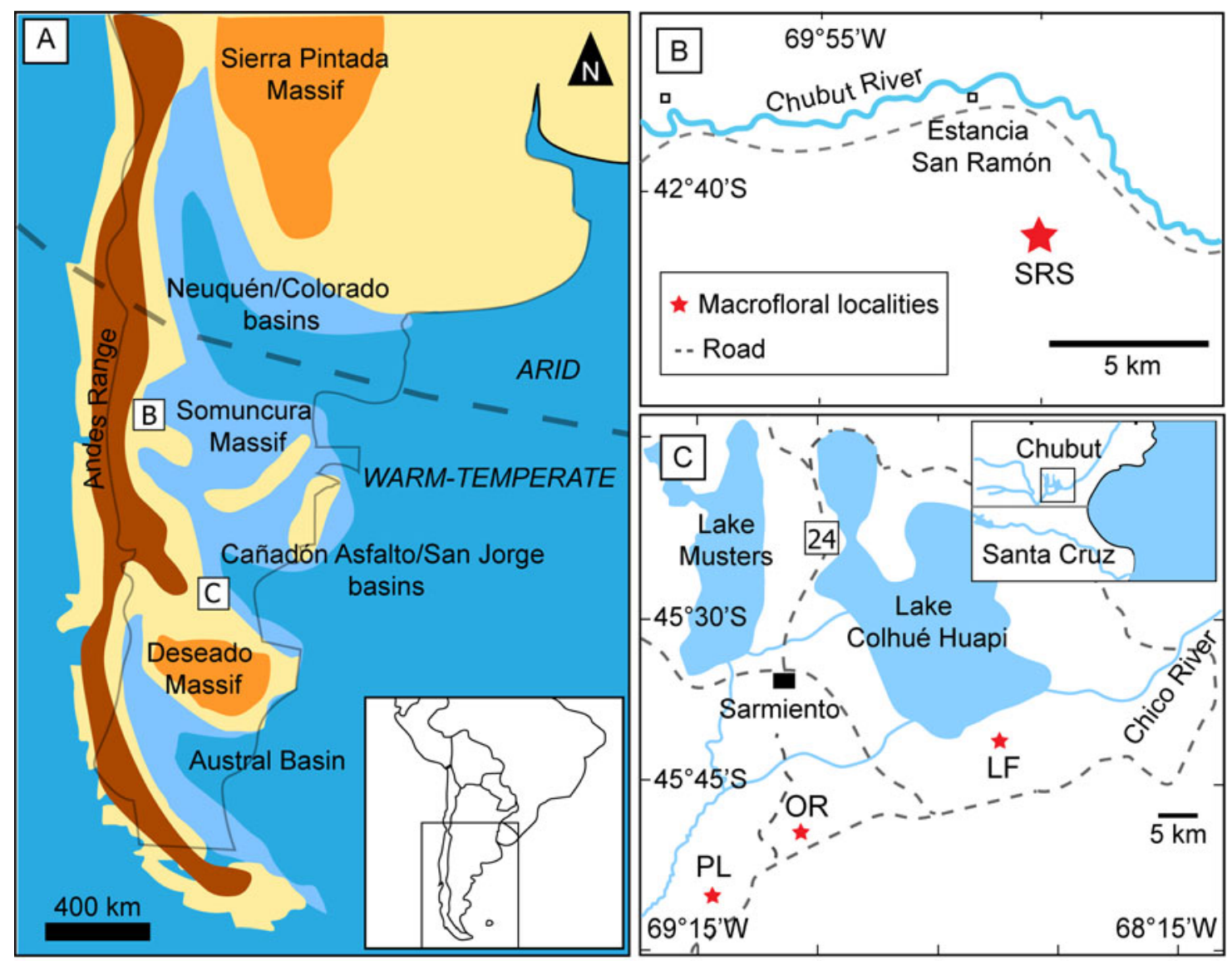

D Northern Chubut
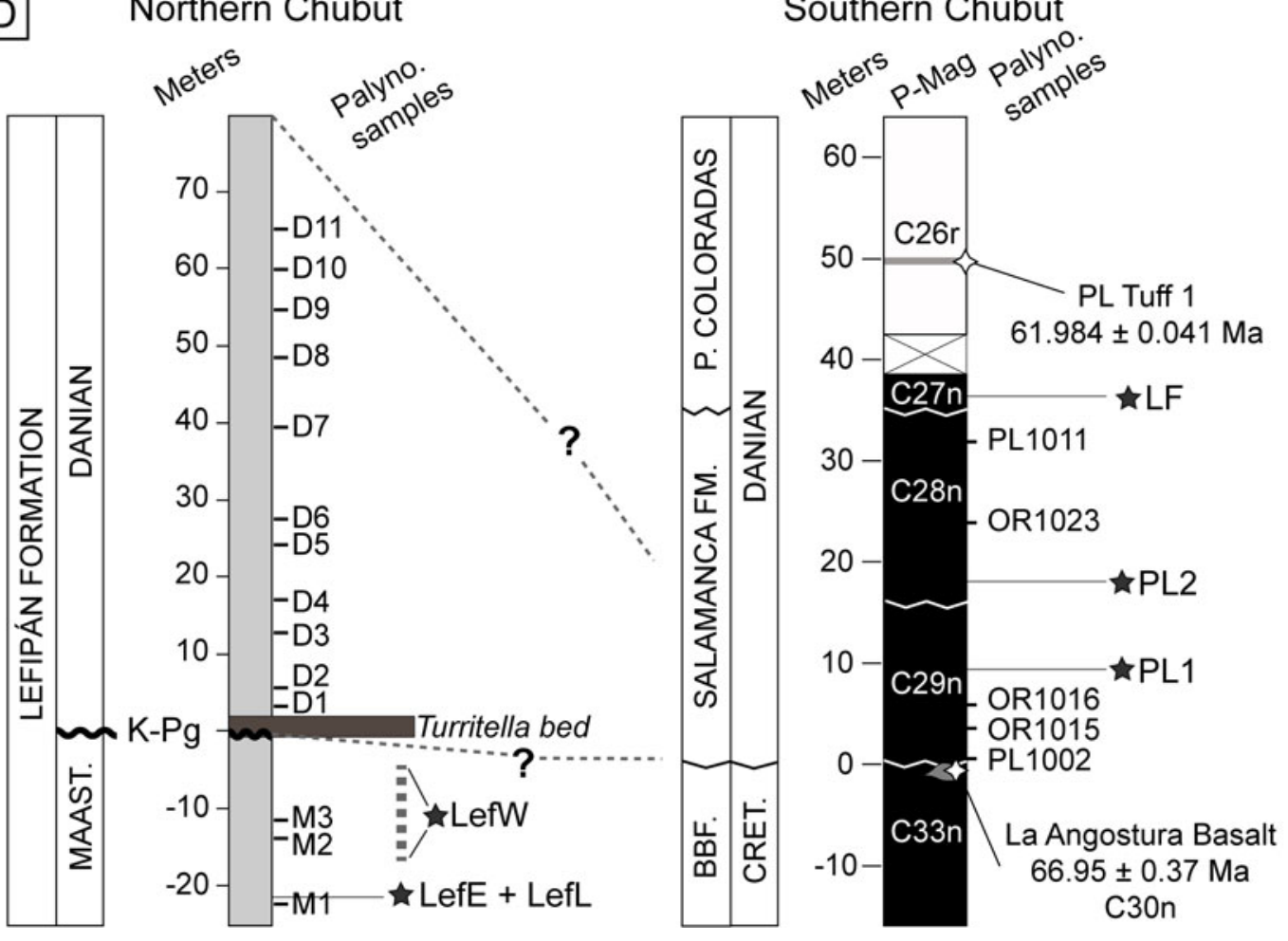
(Martínez et al. 2018), TEX 86 proxy records (Scasso et al. 2012; Vellekoop et al. 2017), and paleobotanical evidence (Baldoni 1992; Baldoni et al. 1993; Barreda et al. 2012; Wilf et al. 2017) indicate that the upper Maastrichtian Lefipán Formation was deposited in mesothermal (or warmer), frostfree climates (Fig. 1A) along a coastline fringed by patchy woodlands and mangroves; macrofossil evidence suggests areas of rain forest as well (Wilf et al. 2017; Escapa et al. 2018).

The San Ramón Section (SRS; Fig. 1B,D) studied here is the most complete of the Lefipán Formation (Scasso et al. 2012), comprising marginal, tidal-flat deposits to fully marine sediments within a tidally dominated deltaic setting that ranges from ?CampanianMaastrichtian to Danian in age (Legarreta and Uliana 1994; Spalletti 1996; Barreda et al. 2012; Scasso et al. 2012; Vellekoop et al. 2017; Butler et al. 2019). The $\mathrm{K} / \mathrm{Pg}$ impact layer recognized at other sites around the world (e.g., Alvarez et al. 1980, 1990; Orth et al. 1981; Brooks et al. 1986; Lerbekmo and St. Louis 1986; Schulte et al. 2010) is not preserved in the SRS, probably due to bioturbation or erosion at that particular level (Scasso et al. 2012). However, the $\mathrm{K} / \mathrm{Pg}$ in the Lefipán Formation is constrained to about $4 \mathrm{~m}$ of section based on biostratigraphic data, including the marker Turritella malaspina lag bed as the first Danian deposit (Fig. 1D) (Medina and Camacho 1990; Scasso et al. 2012), dinoflagellate index taxa (Barreda et al. 2012; Vellekoop et al. 2017), age-diagnostic continental palynomorphs (Barreda et al. 2012), and a sudden and significant turnover of invertebrate faunas
(Aberhan and Kiessling 2014) and microfloras with the extinction of ca. $10 \%$ of total and $50 \%$ of angiosperm palynotaxa (Fig. 1D) (Barreda et al. 2012).

Lefipán Formation specimens analyzed here were collected in the SRS (Fig. 1A,C,D) in sandstone-mudstone tidal-flat deposits (Scasso et al. 2012). Localities LefW, LefE, and LefL, as detailed in Donovan et al. $(2016,2018)$ and Wilf et al. (2017), yielded a total of 1062 dicot-leaf specimens from unbiased collections biostratigraphically constrained to the 67-66 Ma range and most likely in the 66.5-66.0 range based on dinoflagellate markers (Fig. 1D) (Barreda et al. 2012; Scasso et al. 2012; Vellekoop et al. 2017). All identifiable material was collected at these sites and taken back to the MEF, where it was vetted and censused (no identifiable fossils were discarded in the field). The LefW macrofloral site corresponds to the same plant-bearing beds discussed in Scasso et al. (2012) and Vellekoop et al. (2017). The LefW collection (Supplementary Table 3) includes 278 dicot-leaf specimens spanning about $20 \mathrm{~m}$ of stratigraphic section from four collecting horizons, the youngest of which is located $5 \mathrm{~m}$ below the Danian Turritella marker bed (Scasso et al. 2012; Donovan et al. 2016; Vellekoop et al. 2017). Approximately $1000 \mathrm{~m}$ map distance east of LefW is the single fossiliferous horizon yielding the macrofloras of the LefE and LefL collections. Locality LefE, $21.5 \mathrm{~m}$ below the Turritella marker bed, is closest to LefW. The LefE quarry extends about $40 \mathrm{~m}$ along the horizon (Wilf et al. 2017), from where 614 dicot-leaf fossils

FIGURE 1. Setting of paleobotanical localities. A, Paleogeographic reconstruction of Patagonia at K/Pg time, redrawn from Scasso et al. (2012). Light blue diagonal pattern: shallow platform; yellow horizontal pattern: coastal lowlands; dashed line: approximate boundary between paleoclimatic belts as inferred by Scasso et al. (2012). Locations of panels B and C marked. B, Location of Scasso et al.'s (2012) San Ramón section (within star) of the Lefipán Fm., containing Maastrichtian macrofloras and Maastrichtian and Danian palynofloras. Modified after Barreda et al. (2012). C, Locations of Danian paleobotanical sites: Palacio de los Loros (PL), Salamanca Fm.; Las Flores (LF), Peñas Coloradas Fm.; and Bosque Petrificado José Ormachea (OR, Salamanca Fm., used here for pollen data only). Modified after Clyde et al. (2014) and Comer et al. (2015). D, Summary stratigraphy showing chronostratigraphic and absolute age constraints, placement of palynological (tick marks) and macrofloral sampling sites (black stars; compiled from Iglesias 2007; Barreda et al. 2012; Clyde et al. 2014; Comer et al. 2015; Donovan et al. 2016, 2018). Summary of absolute ages of the fossil sites (see text for details): Lefipán floras, 67-66 Ma, most likely 66.5-66.0 Ma; PL1 flora, 66.4-65.7 Ma (C29n); PL2 flora, 64.7-63.5 Ma (C28n); LF flora, 62.562.2 Ma (C27n). Range of stratigraphic section comprising approximate locations of LefW sampling horizons (as described in Vellekoop et al. 2017) indicated by dashed line (see "Materials" for details). LefE, LefL, and LefW are shown on a single column for simplicity but represent different locations (see text for details). LefE and LefL come from a single laterally extensive horizon that varies in stratigraphic distance below the Turritella bed. The position shown is for LefL. BBF, Bajo Barreal Fm. (Color online.) 
were collected. LefL is located approximately $500 \mathrm{~m}$ (map distance) east of LefE, in the same bed, at $24 \mathrm{~m}$ locally below the Turritella bed (Donovan et al. 2016) and yielded 170 dicot-leaf specimens. The single fossiliferous horizon containing LefE and LefL cannot be correlated precisely to those in LefW due to cover and erosion in the intervening landscape, but their ages are probably very similar based on stratigraphic position.

Salamanca and Peñas Coloradas Formations.The Danian Salamanca and Peñas Coloradas Formations are the oldest Cenozoic sedimentary units in the north-central San Jorge Basin (Fig. 1A) (Sylwan 2001; Clyde et al. 2014; Comer et al. 2015). In our study area (Fig. 1A, C), tidally influenced, marginal to estuarine deposits of the early Danian Salamanca Formation (Legarreta and Uliana 1994; Iglesias 2007; Comer et al. 2015) unconformably overlie fluvial and pyroclastic deposits of the Late Cretaceous (Campanian) Bajo Barreal Formation or (where preserved) the Maastrichtian La Angostura Basalt (Fig. 1D) (Iglesias 2007; Clyde et al. 2014; Comer et al. 2015), and they are unconformably overlain by the fluviovolcanic deposits of the late Danian Peñas Coloradas Formation of the continental Rio Chico Group (Fig. 1C,D) (Iglesias 2007; Raigenborn et al. 2010; Clyde et al. 2014; Comer et al. 2015; Krause et al. 2017). At the Las Flores (LF; Fig 1C) Peñas Coloradas Formation locality, deposits overlie the Maastrichtian Colhué Huapi Formation and La Angostura Basalt (Casal et al. 2015; Comer et al. 2015).

Fossil occurrences from the Salamanca and overlying Peñas Coloradas Formations are consistent with humid, mesothermal, frost-free climates (Bonaparte et al. 1993; Brea et al. 2005; Iglesias et al. 2007; Palazzesi and Barreda 2007; Raigemborn et al. 2009; Futey et al. 2012; Clyde et al. 2014; Ruiz et al. 2017, 2020). Palynofloras of the Salamanca Formation and related strata over larger areas reflect a range of environments, from mangrove swamps to lowland and upland forests (Petriella and Archangelsky 1975; Zamaloa and Andreis 1995; Volkheimer et al. 2007). In the study area (Fig. 1C,D), local pollen records show diverse, angiospermdominated lowland forests (Petriella and Archangelsky 1975; Clyde et al. 2014).
The unbiased, lab-vetted (the same collecting and tallying methods used as for the Lefipán floras) early Paleocene leaf collections analyzed in this study came from two early Danian Salamanca Formation localities in the Palacio de los Loros sampling area (PL1 and PL2) and one late Danian locality in the Peñas Coloradas Formation, the LF plant-fossil site (Fig. 1B) (Iglesias 2007; Iglesias et al. 2007; Clyde et al. 2014). Biostratigraphic data from foraminifera, dinoflagellates, and calcareous nannoplankton indicate the early Danian age for the local Salamanca Formation, with a maximum absolute age of $67.31 \pm 0.55 \mathrm{Ma}$ from ${ }^{40} \mathrm{Ar} /{ }^{39} \mathrm{Ar}$ dating of the La Angostura Basalt flow underlying the formation in the easternmost exposures of the study area (Fig. 1D) (Clyde et al. 2014). The U-Pb age of a tuff layer in the Peñas Coloradas Formation at Palacio de los Loros is 61.984 $\pm 0.041 \mathrm{Ma}$, placing it in the late Danian (Fig. 1D) (Clyde et al. 2014). Combined analysis of paleomagnetic stratigraphy, biostratigraphy, and $\mathrm{U}-\mathrm{Pb}$ and ${ }^{40} \mathrm{Ar}-{ }^{39} \mathrm{Ar}$ ages place the paleobotanical sites PL1, PL2, and LF within geomagnetic polarity chrons C29n (65.58-64.88 Ma), C28n (64.67-63.49 Ma), and C27n (62.52$62.22 \mathrm{Ma}$ ), respectively (Fig. 1D) (Clyde et al. 2014; Comer et al. 2015), using the 2012 Geologic Time Scale (Gradstein et al. 2012).

Between the early Danian Salamanca and late Danian Peñas Coloradas Formations, there is a sharp change in the depositional environment. The strata at PL1 and PL2 were deposited in marginal estuarine settings, whereas LF was deposited in a nearly fully terrestrial fluvio-volcanic environment (Comer et al. 2015). Locality PL1 (Fig. 1A,C,D) produced 1089 dicot-leaf specimens, preserved in sand-siltstone sediments interpreted as lateral accretion beds of abandoned tidal channel fill (facies $S_{a b}$ in Comer et al. 2015). The younger locality PL2 yielded 1132 dicot-leaf specimens, collected from silty claystones interpreted as the transitional facies of tidal flats prograding over a coastal plain (facies $S C_{t}$ in Comer et al. 2015). Sediments in locality LF are the coarsestgrained of the Danian macrofloral sites, from where 564 dicot-leaf specimens were recovered from poorly sorted litharenites interpreted as channel fills (facies LF1 in Comer et al. 2015). Based on sedimentology and preservational 
quality, the potential order of transport distances for fossil leaves is ranked highest to lowest as LF, PL1, and PL2. Donovan et al. (2018) noted that preservation quality in Salamanca Formation locality PL1 is similar to that of the Lefipán Formation, indicating minimal preservation bias between the oldest Paleogene locality and the Maastrichtian collections in this study.

\section{Analytical Methods}

Macrofloral turnover across the $\mathrm{K} / \mathrm{Pg}$ transition was addressed through analyses of (1) change in species composition, (2) morphospace shifts among assemblages, and (3) the potential biasing effect of the ca. $400 \mathrm{~km}$ separation between the Cretaceous and Paleogene collection sites using crosschecks from local pollen records in both formations (Fig. 1D). Preliminary Lefipán Formation morphotypes (Donovan et al. 2016) were significantly revised and updated based on leaf architectural characters (Ellis et al. 2009). Danian morphotypes of the Salamanca and Peñas Coloradas Formations are based on the morphotype set of the PL1, PL2, and LF macrofloral localities (Iglesias 2007; Iglesias et al. 2007) and an additional set published in the supplementary information of Donovan et al. (2016; Supplementary Table 4). A total of 58 Maastrichtian and 43 Danian morphotypes were established and used in the subsequent analyses (Supplementary Table 4). Each morphotype is here interpreted as likely to have been produced by a single species with morphologically distinct leaves and will be referred to as a species throughout this study. An updated specimenlevel collections inventory of all leaf morphotypes as used here is archived in Supplementary Table 3.

Extinction and Turnover.-All Maastrichtian and Danian collections were grouped into two respective assemblages for macrofloral extinction estimates and morphospace analyses due to their self-similar floral compositions and morphospace occupation, based on preliminary analyses. Each of the Maastrichtian morphotypes was compared with the Danian morphotypes in search of $\mathrm{K} / \mathrm{Pg}$ survivor pairs based on a detailed comparison of their leaf architecture (per Johnson et al. 1989; Ash et al. 1999; Ellis et al. 2009). Maastrichtian and Danian morphotypes that shared all morphological characters or that fell within each other's ranges of variation were considered survivor pairs.

Once the survivor pairs were established, they were each considered as a single species, along with all the other leaf species, in a principal components analysis (PCA) applied to a matrix of species abundances per sample, with the objective of testing compositional heterogeneity among the considered Maastrichtian and Danian macrofloral collections. In this analysis, Maastrichtian collections LefW and LefE+LefL were considered as two samples, because LefW was collected along several horizons within the same small canyon (see "Materials"), and LefE and LefL were collected along the same fossiliferous horizon.

For rarefied (Tipper 1979) species richness analysis across the $\mathrm{K} / \mathrm{Pg}$, the Maastrichtian LefE and LefL sites were grouped into a single sample, from which LefW was excluded because it includes specimens from multiple horizons with uncertain stratigraphic relationships to horizon LefE+LefL. The Salamanca (PL1 and PL2) and Peñas Coloradas (LF) localities (Fig. 1A,C,D) (Iglesias 2007; Iglesias et al. 2007) were considered for rarefaction individually because they span three Danian time intervals (Fig. 1D) (see "Materials"; Clyde et al. 2014; Comer et al. 2015). Each rarefaction curve was plotted with a $95 \%$ confidence interval using the R package iNext (Hsieh et al. 2016).

As a baseline for comparison of rarefied species richness between Patagonian and North American $\mathrm{K} / \mathrm{Pg}$ assemblages, three representative dicot-leaf samples surpassing 350 specimens each (per Burnham 1993) from meter-binned collections of the Maastrichtian Hell Creek and Danian Fort Union Formations in the WB of southwestern North Dakota were selected from the dataset of Wilf and Johnson (2004; see also Johnson 2002). The Dean Street level found $15 \mathrm{~m}$ below the K/Pg boundary (Wilf and Johnson 2004) represents the most diverse, latest Maastrichtian HCIII zone (Johnson 2002). Two representative Fort Union Formation collection horizons were based on specimen counts $>350$ and 
magnetostratigraphic constraints. Horizon +7 $\mathrm{m}$ is the most specimen-rich representative of early Danian Fort Union Formation fossil horizons, corresponding to geomagnetic polarity chron C29r (which is unrecorded in Patagonia). The $+38 \mathrm{~m}$ horizon is constrained to chron C29n (Hicks et al. 2002; Johnson 2002), serving as a temporal analog to the PL1 locality in Patagonia (Fig. 1D) (Clyde et al. 2014). While acknowledging work on diverse Paleocene floras from the more southerly Denver and San Juan basins (Johnson and Ellis 2002; Flynn and Peppe 2019; Lyson et al. 2019), we focus on the floras of the WB for comparison, because they come from similar absolute paleolatitudes to our samples (i.e., ca. $51.3^{\circ} \mathrm{S}$ for the Danian Patagonian floras, ca. $48.4^{\circ} \mathrm{S}$ for the Cretaceous Lefipán floras, and ca. $49.4^{\circ} \mathrm{N}$ for the WB floras, versus ca. $42.5^{\circ} \mathrm{N}$ for the Denver Basin, following Iglesias et al. 2007: fig. 3), contain both Cretaceous and Paleocene floras that are well sampled in a single area, and remain the best-sampled and described boundary-spanning K/Pg macrofloras of NAM.

Morphospace Analysis.-Species richness and morphological diversity are not always coupled, and this disconnection may be driven by underlying selective pressures (Foote 1993; Roy and Foote 1997). Morphospace analysis is here used as a quantitative tool to measure morphological diversity and phenotypic relationships among angiosperm leaf species and their change through time, by summarizing morphological characters in a mathematical space where phenotypic dissimilarities are observed as graphical distances (Mitteroecker and Huttegger 2009). Leaf architecture is related both to systematic affinities and environmental parameters (e.g., Wolfe 1995; Wilf 1997; Little et al. 2010; Givnish and Kriebel 2017), making leaves ideal candidates to simultaneously test species and morphological turnover across the $\mathrm{K} / \mathrm{Pg}$. Through morphospace analysis, the multivariate relationships among characters can shed light on selective morphological extinction patterns, if present, and the relationships between morphological disparity and species richness.

Based on the Manual of Leaf Architecture (Ellis et al. 2009), forty-six discrete shape, size, margin, and venation characters (Supplementary
Table 5) were scored for each of the Maastrichtian and Danian morphotypes (Supplementary Table 7). Features that were not preserved (or observable) in at least three-fourths of the specimens, such as fourth- and higher-order venation, were excluded to reduce noise in the dataset. After observation of all available material, character states for each morphotype were usually based on one or two (if a single specimen did not preserve all morphological characters) selected exemplar specimens. If a morphotype showed significant variation in one or more characters after observation of all available samples, end members were separated in the morphological matrix designated by letters following the morphotype name (e.g., SA9A, SA9B; Supplementary Table 7) to ensure that all morphological diversity was captured in the subsequent ordination. Maximum size was based on the largest specimen of each species in the collection. Missing characters were coded as "NA."

The morphological matrix (Supplementary Table 7) was ordinated using principal coordinates analysis (PCoA) with the R Package ape (Paradis and Schliep 2018). Because it compares each morphotype on a character-by-character basis, PCoA is considered the best-performing method for datasets with uneven preservation and missing characters (Foote 1994; Roy and Foote 1997). The percentages of missing data for each character and each morphotype are reported in Supplementary Table 8. To understand how species are distributed in space and to explore possible character-related patterns, the same scores obtained in the PCoA ordination were analyzed by graphically superimposing character states on plotted scores including axes PCoA $1-\mathrm{PCoA} 3$. The process was repeated for each character.

To obtain a quantitative measure of morphospace occupation for Maastrichtian and Danian assemblages and to verify consistency in the results, four disparity measures were calculated separately for each Maastrichtian (LefW, LefE, and LefL) and Danian (PL1, PL2, and LF) leaf assemblage and for grouped Maastrichtian (LefW+LefE+LefL) and Danian (PL1 + PL2+LF) assemblages. Based on the first four axes of the PCoA, (1) a hypercuboid volume and (2) a sum of ranges were estimated 
(Foote 1994; Wills et al. 1994). Based on the Euclidean pairwise distance matrices, the (3) average pairwise distance and (4) maximum pairwise distance were extracted. The hypercuboid volume was estimated by multiplying the ranges of the first four axes (Wills et al. 1994). Following Gerber's (2019) proposed measures of disparity for discrete character spaces, the (3) average and (4) maximum pairwise distances of the Euclidean distance matrix are reported here (Supplementary Table 6) for each local assemblage and the grouped Maastrichtian and Danian assemblages.

Pollen Analysis and Regional Floral Heterogeneity.-Palynological records from the same formations and sections offer the closest possible points of comparison to macrofloras, and they provide, for the most part with taxonomic resolution above the species level, information about changes in regional floral composition (Behrensmeyer et al. 2000; Nichols and Johnson 2008). To evaluate the effects of the approximately $400 \mathrm{~km}$ distance separating the Maastrichtian and Danian localities (Fig. 1A) as a spatial bias affecting macrofloral composition, published palynological records for the same two sampling areas and stratigraphic framework (Fig. 1D) (Barreda et al. 2012; Clyde et al. 2014) were compared at taxon-by-taxon and whole-assemblage levels. The Lefipán Formation palynological records from the SRS span the boundary (Fig. 1D) (unlike the Lefipán macrofloras; Barreda et al. 2012); thus, both their Maastrichtian and Danian components were compared with the exclusively Danian records of the Salamanca Formation at Palacio de los Loros and adjacent areas sampled at high stratigraphic resolution (Clyde et al. 2014). We note that several other palynological studies exist of both formations based on other sections (e.g., Archangelsky 1973; Petriella and Archangelsky 1975; Medina and Camacho 1990; Baldoni et al. 1993; Casal et al. 2015), but our goal is to compare palynological data from the same wellconstrained sections as the macrofloras addressed here. The fine temporal correlations between the Lefipán and Salamanca Formations are not yet established.

V. Barreda (Museo Argentino de Ciencias Naturales, Buenos Aires) kindly reviewed the illustrations and species lists in Clyde et al. (2014) to establish equivalencies between palynotaxa (e.g., "Proteaceae sp. A" and "Proteaceae sp. B") among the Lefipán and Salamanca sections, and her vetted species data were used in subsequent analyses (Supplementary Table 2). Sample-level compositional comparisons were based on a presenceabsence matrix of palynomorph species and morphotypes (Supplementary Table 2) and processed in the $R$ vegan package (Oksanen et al. 2017).

The presence-absence matrix of palynomorph data was transformed using the Beals smoothing method (McCune 1994; Münzbergová and Herben 2004), which accounts for unevenness in ecological sampling by replacing species' presence data with a probability of occurrence based on co-occurrences in the sample pool. This method was used to reduce the underlying compositional heterogeneity caused by the inherent sampling bias of the fossil record. The samples were then clustered based on their Bray-Curtis pairwise dissimilarity matrix calculated from the Beals-smoothed dataset and linked using Ward's method algorithm (Oksanen et al. 2017).

\section{Results}

Extinction and Turnover.-We recognize only five Maastrichtian leaf species as having a corresponding survivor in any Danian assemblage (Figs. 2, 3), indicating a raw dicot macrofloral extinction of $92.2 \%$. Using only the oldest Danian assemblage (PL1 locality) yields a 93.3\% extinction. Excluding species represented by a single specimen (singletons) reduces the extinction slightly, to $90.6 \%$. The $\mathrm{K} / \mathrm{Pg}$ survivor pairs based on Maastrichtian (prefix LEF) and Danian (prefix SA) morphotypes (Supplementary Tables 1,2) are referred to as Survivor Pair (SP) 1 (LEF57-SA20; Fig. 2A-E), SP2 (LEF64-SA35; Fig. 2F-I), SP3 (LEF6-SA19; Fig. 3A-C), SP4 (LEF18-SA08; Fig. 3D-G), and SP5 (LEF55-SA78; Fig. 3H-J).

We interpret SP1 (Fig. 2A-E) to have a botanical affinity with the family Cunoniaceae based on its architectural characters including compound leaves (Fig. 2), supported by the welldocumented presence (and earliest global 

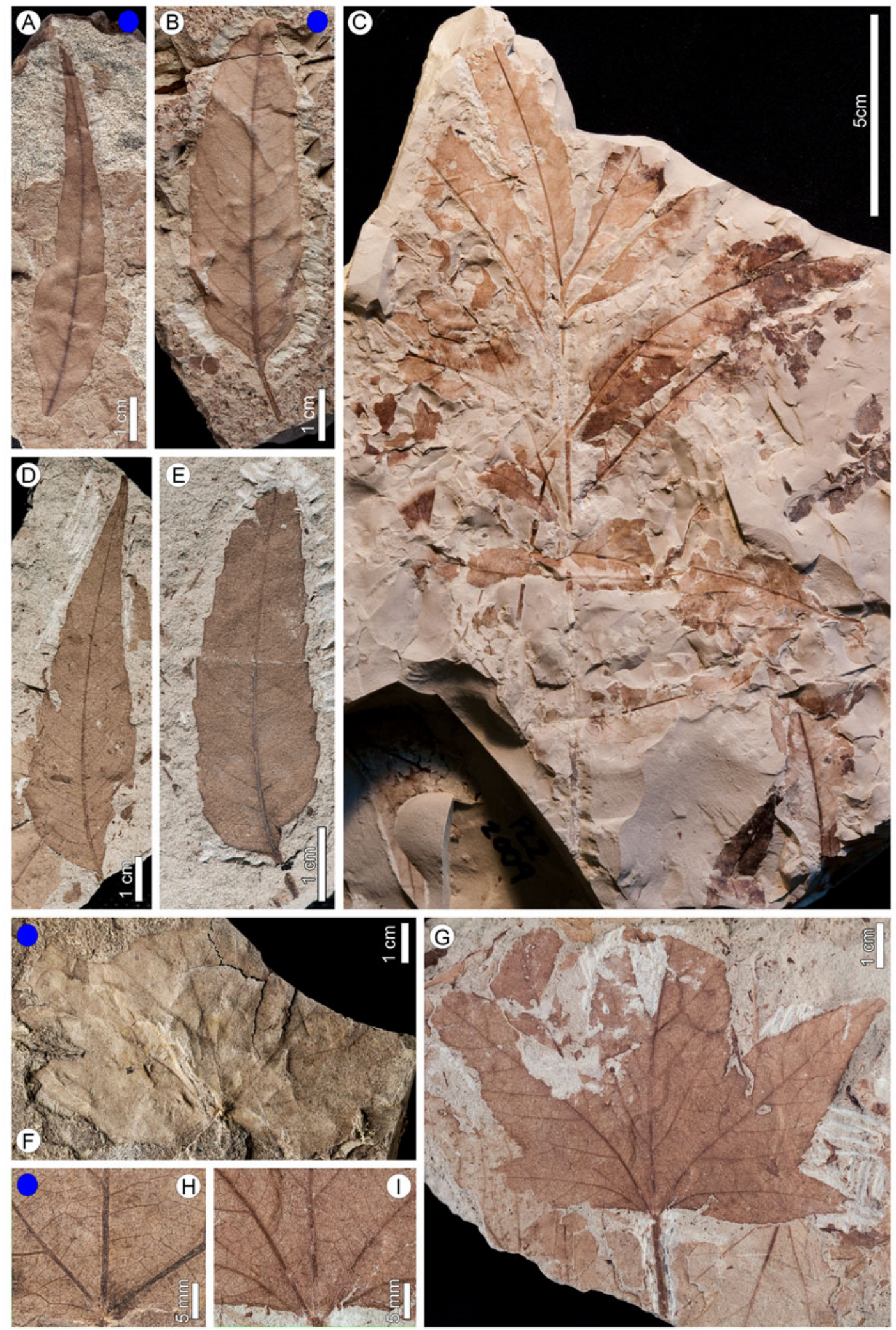
macrofossil occurrence) of this family from abundant co-occurring Lacinipetalum spectabilis flowers with in situ pollen (schizomerioid Cunoniaceae; Jud et al. 2018) from PL2 and other Salamanca Formation localities and fossil wood in the Peñas Coloradas Formation (Raigemborn et al. 2009). The affinities of SP2 (Fig. 2F-I) and SP5 (Fig. 3H-J) remain unknown. Following Iglesias et al. (2007), SP3 (Fig. 3A-C) is equivalent to some specimens designated as "Sterculia" acuminataloba Berry 1937 of the family Malvaceae, and SP4 (Fig. 3D-G) belongs to the family Rosaceae based on diagnostic characters including serrated margins with compound teeth and craspedodromous secondary venation. The survivorship of the family Rosaceae is a new contribution of this study, along with Cretaceous macrofloral evidence to support the $\mathrm{K} / \mathrm{Pg}$ survival of Malvaceae and Cunoniaceae, previously known from pollen records in these sections (Barreda et al. 2012; Jud et al. 2018a,b).

Laurophyll morphotypes observed in this study provide evidence for the $\mathrm{K} / \mathrm{Pg}$ survival of the Lauraceae in Patagonia, although we cannot assign any Maastrichtian laurophyll to a definite Danian species-level equivalent because they lack cuticular preservation for further analysis (e.g., Carpenter et al. 2018). Based on a conservative "lumping" approach, we established four Maastrichtian laurophyll morphotypes based on their having typical lauraceous leaf architectural features (after Hickey and Wolfe 1975). Lefipán Formation morphotypes LEF08, LEF24, LEF26, and LEF32 (Supplementary Table 3), coupled with Danian Laurophyllum piatnitzkyi Berry and Laurophyllum chubutensis Berry of the Salamanca and Peñas Coloradas Formations (Iglesias et al. 2007), add Lauraceae to the list of Patagonian $\mathrm{K} / \mathrm{Pg}$ macrofloral survivor families. Laurophyllum piatnitzkyi is notable as the most abundant species in the Danian assemblages, accounting for ca. $17 \%$ of total leaf specimens (Iglesias et al. 2007).

The loss of common taxa followed by the emergence of previously rare taxa is a commonly observed pattern across mass extinction intervals (e.g., Erwin 2002; Johnson 2002; Jablonski 2005). A comparable pattern occurs in our survivor pairs (Fig. 4). SP1 of the Cunoniaceae (Fig. 2A-E) is a major component of Maastrichtian floras, but its abundance is greatly reduced at earliest Danian PL1 before partially recovering in PL2 (Fig. 4). In contrast, Malvaceae SP3 (Fig. 3A-C) and Rosaceae SP4 (Fig. 3D-G), both minor components in Maastrichtian assemblages, surpass $5 \%$ of assemblage composition at early Danian PL1 and are reduced back to minor components at PL2 and LF (Fig. 4). Leaf morphotypes SP2 and SP5, of unknown affinities, remain minor components throughout.

Rarefied dicot-leaf richness dropped in Patagonia by almost $40 \%$ across the $\mathrm{K} / \mathrm{Pg}$ and remained comparably low from the early to late Danian (Fig. 5). Patagonian Danian floras are remarkably homogeneous across time and facies, from early to late Danian and from marginal marine to pyroclastic-fluvial environments, in comparison with the relatively more heterogeneous Lefipán floras deposited in similar facies and spanning a narrower time interval (Fig. 6). A sharp drop in rarefied species richness was also observed in the North American $\mathrm{K} / \mathrm{Pg}$ floras of the WB in North Dakota (e.g., Johnson 2002; Wilf and Johnson 2004). However, our rarefaction also shows that Patagonian floras are significantly more diverse than the North Dakota floras not only during the early Danian (Iglesias et al. 2007) but also the Maastrichtian (Fig. 5).

Morphospace Analysis.-Pre- and post-K/Pg leaf assemblages significantly overlap in

FIGURE 2. K/Pg survivor pairs (SPs) from the Maastrichtian Lefipán (blue circles) and Danian (unmarked) Salamanca and Peñas Coloradas Formations (see also Fig. 3). A-E, SP1, Cunoniaceae, including articulated compound leaf. Note ovate and asymmetrical blades of variable leaflets, curved primary vein, craspedodromous secondary venation, mixed percurrent tertiaries perpendicular to secondaries, and small triangular teeth with long-rounded sinuses. A, MPEF-Pb-4416 from locality LefE; B, MPEF-Pb-4349, LefE; C, MPEF-Pb-9154 from locality PL2; D, MPEF-Pb-3691, PL1; E, MPEF-Pb-3694, PL1. F-I, SP2. Note well-developed palmate lobing, toothed margin, straight secondaries with opposite insertion, compound agrophic veins, and alternate percurrent tertiaries. F, MPEF-Pb-3701a, LefL; G, MPEF-Pb-2031, PL1; H, MPEF-Pb-3701b detail of alternate percurrent venation; I, MPEF-Pb-2031 (also $\mathrm{H}$ ) detail of alternate percurrent venation. (Color online.) 

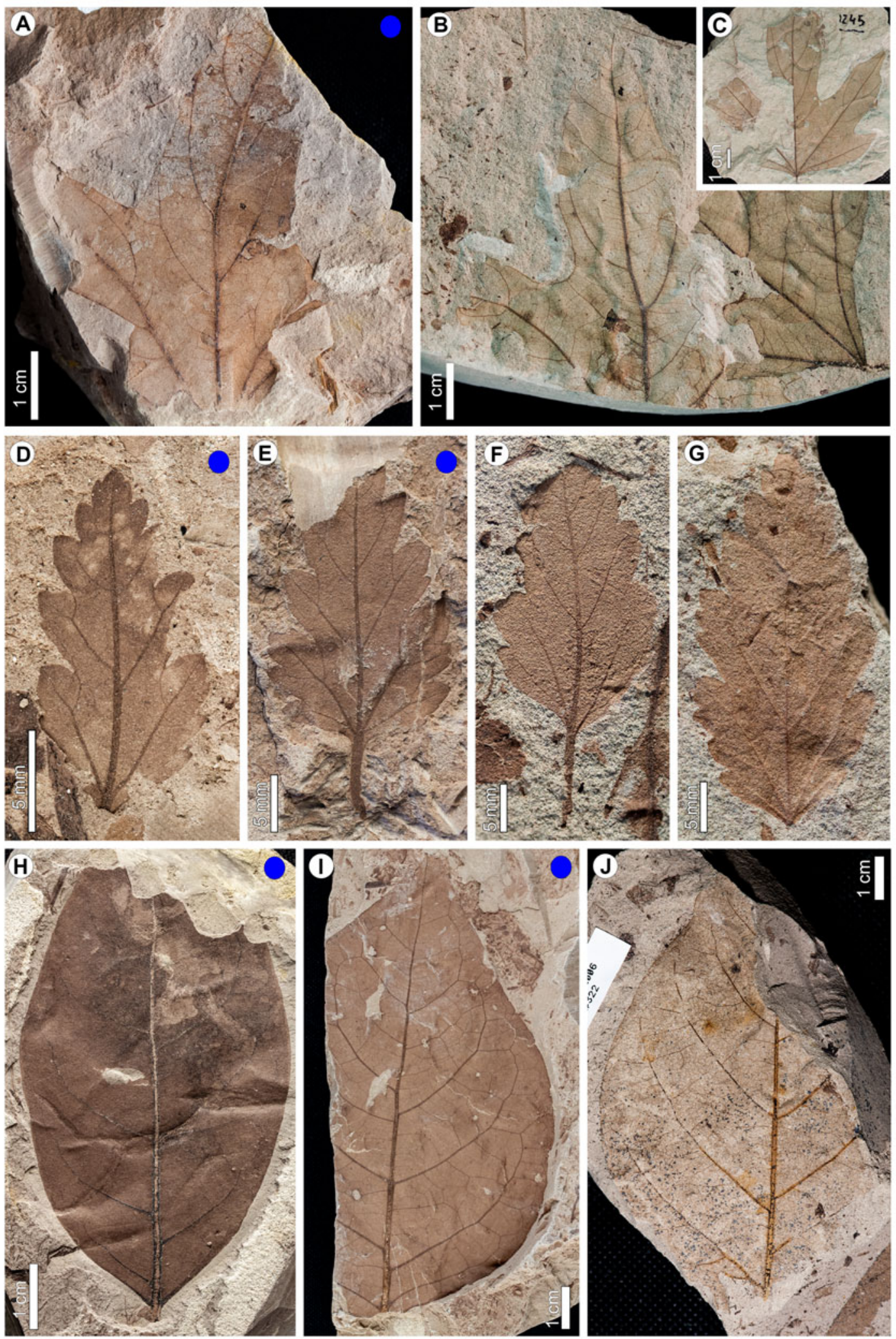
FIGURE 3. K/Pg survivor pairs (SPs; continued from Fig. 2) from the Maastrichtian Lefipán (blue circles) and Danian (unmarked) Salamanca and Peñas Coloradas Fms. A-C, SP3, "Sterculia” acuminataloba. Note the palmately lobed form with entire margins, three strong primary veins, central primary deflected by strong basal secondaries, interior secondaries, intersecondary veins, agrophic veins, irregularly branching brochidodromous secondaries with spacing decreasing apically, and percurrent tertiaries nearly perpendicular to the primary vein. A, MPEF-Pb-4662a from locality LefW; B, MPEF-Pb-3692, PL1; C, MPEF-Pb-3695, PL2. D-G, SP4, Rosaceae similar to Crataegus spp. Note ovate shape, craspedodromous secondaries, pinnate lobing with toothed lobes, large triangular teeth, opposite to subopposite secondaries. D, MPEF-Pb-4487, LefE; E, MPEF-Pb-4482, LefE; F, MPEF-Pb-3693, PL1; G, MPEF-Pb-4030, PL1. H-J, SP5. Note ovate-elliptic leaf shape, opposite to subopposite concave-upward brochidodromous secondaries, intersecondary veins perpendicular to primary, widely spaced irregularly angled tertiaries ranging from opposite to alternate percurrent, and fimbrial vein running along entire margin. H, MPEF-Pb-4870, LefL; I, MPEF-Pb-4835, LefE; J, MPEF-Pb-3019, LF. (Color online.)

morphospace, but there is an increase in morphospace occupation between the terminal Cretaceous and early Paleogene (Fig. 7). This result shows no significant loss of characters and higher morphological disparity in postcompared with pre-K/Pg assemblages, despite lower species richness in the Danian. Morphospace occupation across the $\mathrm{K} / \mathrm{Pg}$ is characterized by three notable shifts. First, morphospace volume expands, driven by Danian lobed species displaying blade incision characters absent in the Maastrichtian. Examples include lobed species with toothed margins such as SA35 (see circled groups in Fig. 8A). Second, within the morphospace area shared by Maastrichtian-Danian assemblages (Fig. 8), more Danian species have lobed blades, toothed margins, and craspedodromous venation.
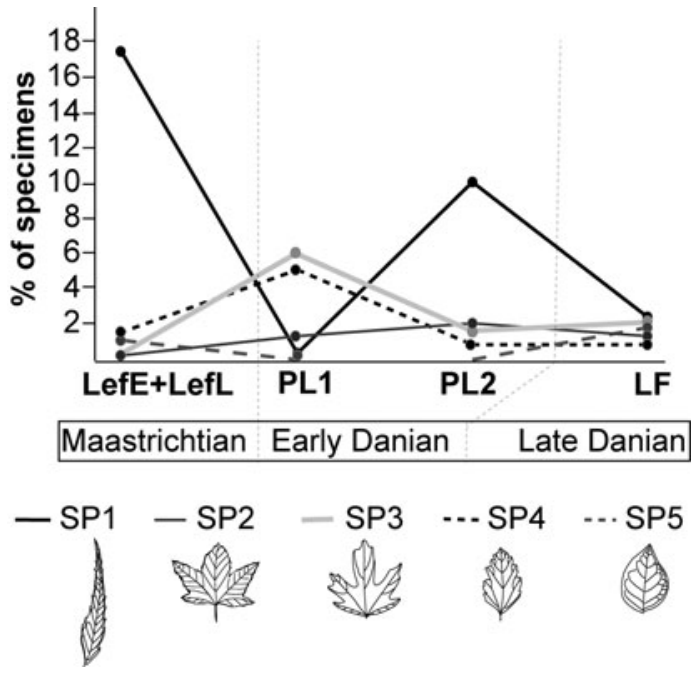

FIGURE 4. Relative abundance of each survivor pair (SP; see Figs. 2, 3) in total leaf counts from Maastrichtian and Danian floral assemblages.
Third, extremes in morphological variation, seen as end members along the PCoA axes, are all represented by Danian species, signaling higher morphological disparity in post- $\mathrm{K} / \mathrm{Pg}$ assemblages (Fig. 8). For example, with the lowest score along axis PCoA 1, Danian species SA35 (Fig. 8A, lower left) is lobed with craspedodromous secondary veins and toothed margins, whereas SA50 (Fig. 8B, upper right), with the highest score for axis PCoA 1 , is unlobed with entire margins and
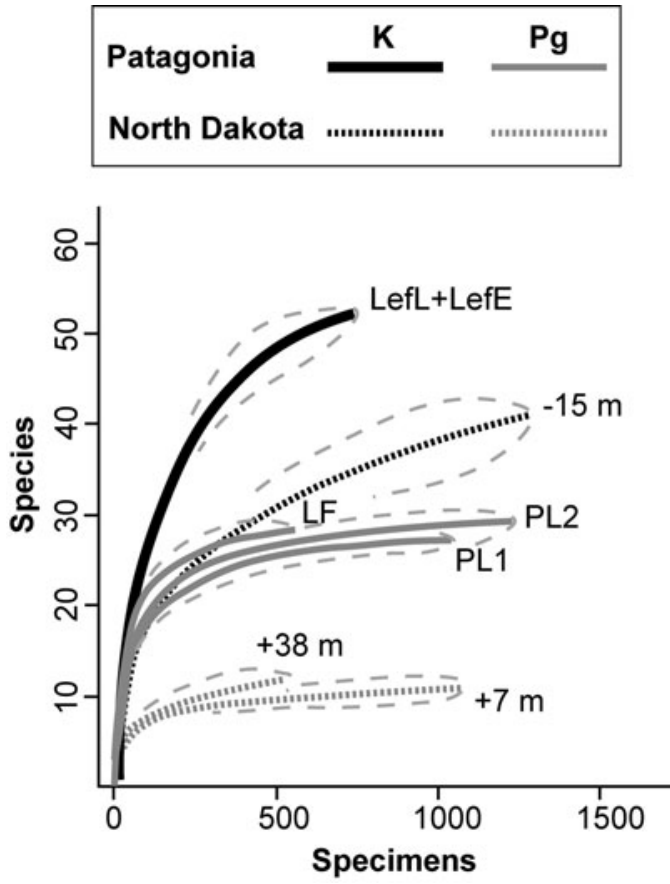

FIGURE 5. Rarefied leaf species richness with 95\% confidence intervals for Patagonian sites (solid lines, this study) and Williston Basin, North Dakota (dashed lines, denoted with meters below or above $\mathrm{K} / \mathrm{Pg}$ impact layer; data from Wilf and Johnson 2004). Data include all Maastrichtian (black) and Danian (gray) dicot-leaf samples, including singleton species (see "Methods" for details). 


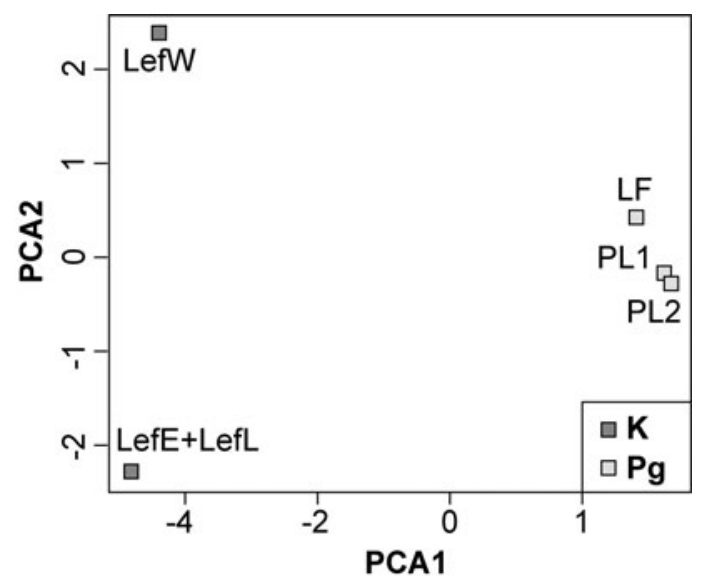

FIGURE 6. Compositional differences between Maastrichtian (K) and Danian (Pg) assemblages based on a species by abundances principal components analysis (PCA), showing increased similarity of floral composition from the Maastrichtian (Lef) to the Danian (PL, LF) macrofloras, even though the Danian assemblages represent a longer time interval and a much greater array of facies types. PCA 1 variance explained $=72.7 \%$, PCA 2 variance explained $=11.5 \%$.

brochidodromous venation. Intermediate morphotypes along PCoA 1 display combinations of entire and toothed-margined characters and additional, less common venation types. Maastrichtian morphotypes cluster toward the higher scores of PCoA 1 and most share morphological characteristics with SA50, such as entire margins, no lobes, and brochidodromous secondaries (Fig. 8).

When we analyzed morphospace occupation by character states (Supplementary Table 5), the most significant observable variation was found in characters of maximum blade size, lobation, and margin types. Maximum leaf size ranges from nanophyll to megaphyll, with representatives of both Maastrichtian and Danian species in each size class. The representation of both Maastrichtian and Danian leaves within the same size class range could indicate isotaphonomic leaf assemblages. However, for purposes of morphospace analysis, leaves in the smallest (nanophyll) and largest (macrophyll and megaphyll) size classes were excluded, because they included too few specimens to produce an interpretable morphospace occupation pattern. Individually plotting the ordination scores by maximum leaf size classes of each species (Fig. 9), we found that shifts in morphospace occupation across the $\mathrm{K} / \mathrm{Pg}$ become more significant as maximum leaf size increases (Figs. 7, 9).

Within each size class, there appear to be distinct morphological trends (Fig. 9). In the
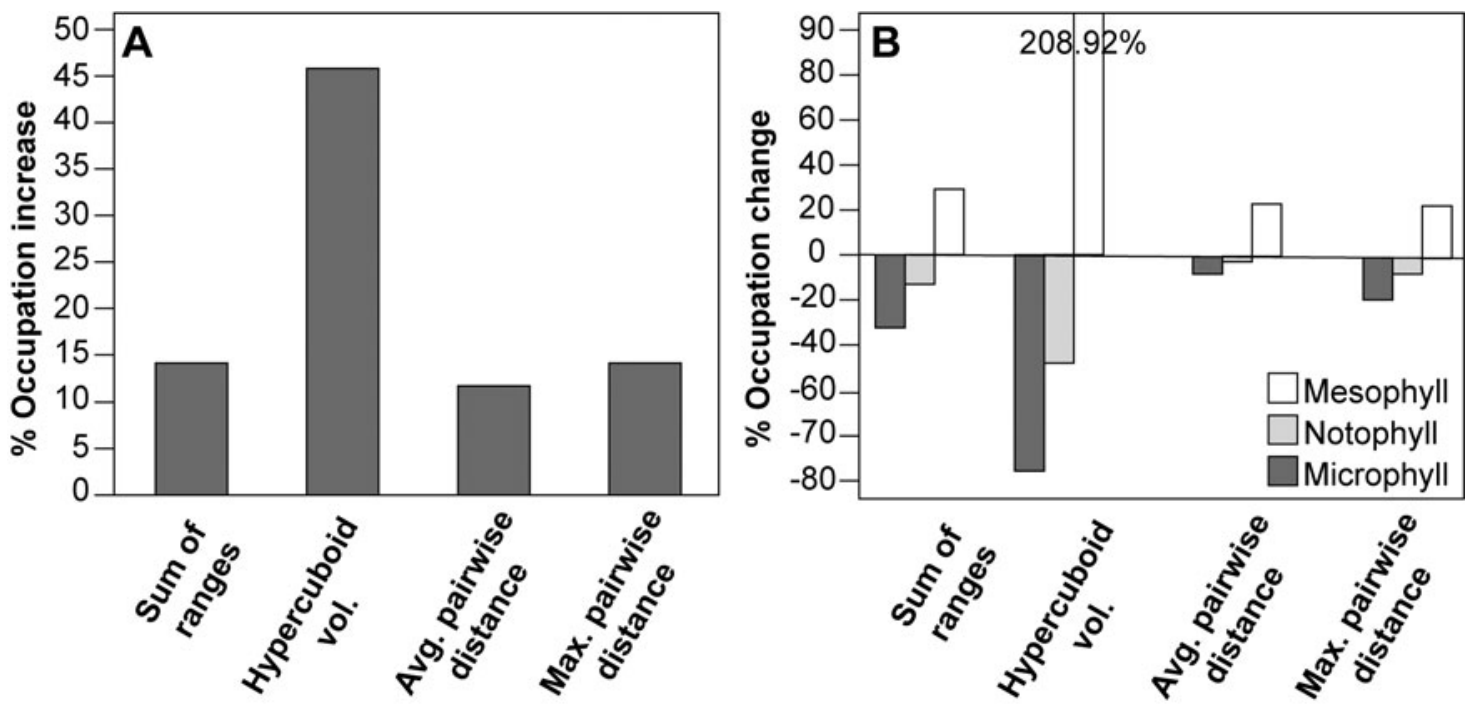

FIGURE 7. Percentage increase in leaf morphospace occupation from Maastrichtian to Danian in Patagonia based on four measures of disparity (see "Methods" for details). A, Morphospace volume increase based on all Maastrichtian and Danian species. B, Morphospace area change partitioned by most common leaf size classes. 


\section{- Maastrichtian species $\Delta$ Danian species}
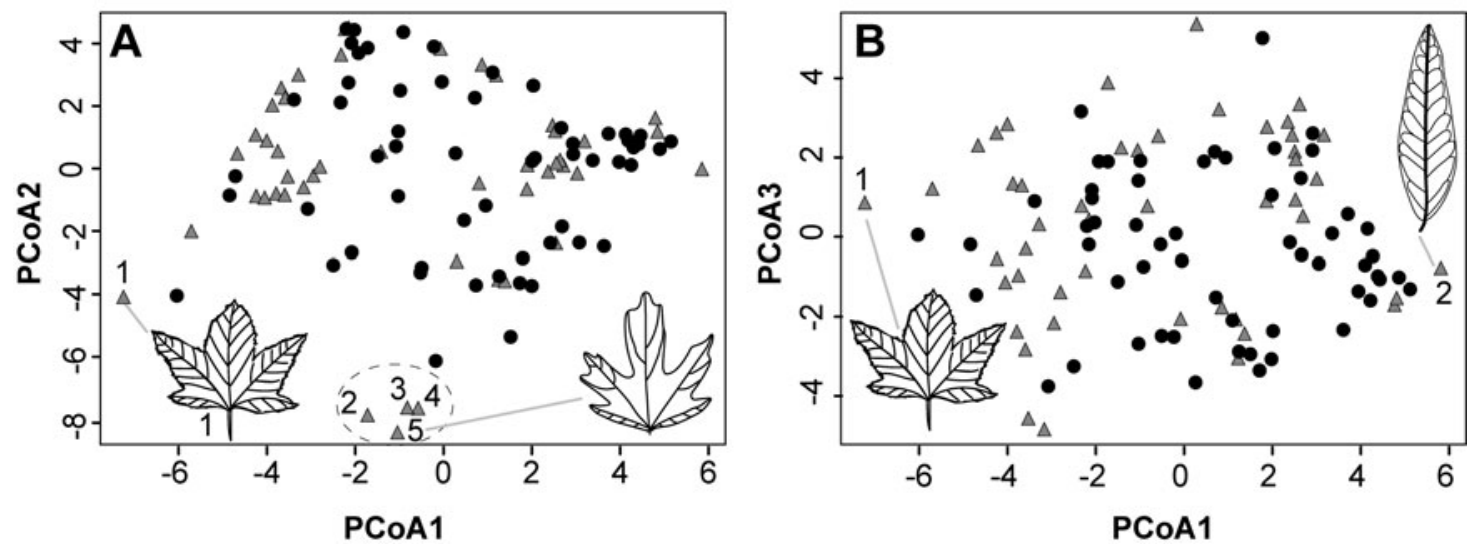

FIGURE 8. Morphospace occupation of Maastrichtian and Danian assemblages from principal coordinates analysis (PCoA). The expanded Danian morphospace (see Fig. 7) indicates higher morphological diversity in post-K/Pg floras despite lower species richness. A, Axis 2 vs. axis 1. Characteristically lobed outliers driving Danian morphospace expansion are recognized as two groups as circled; labeled exemplar species are: 1, SA35; 2, SA39; 3, SA55; 4, SA19A; 5, SA19B. B, Axis 3 vs. axis 1. Morphological end members along PCoA 1, both Danian, labeled: 1, SA35; 2, SA50.

smallest size classes, microphylls and notophylls, Maastrichtian leaves occupy a larger morphospace than Danian species, as shown by the four end members along axes 1 and 2 (Fig. 9A, labeled 1-4; Fig. 9B, labeled 1, 2, and $4)$. This result is supported by a reduction in morphospace volume (Fig. 7B), indicating that leaves in these size classes are more morphologically diverse in Maastrichtian assemblages. In contrast, the larger mesophyll-sized leaves (Fig. 9C) expand in morphospace occupation after the K/Pg (Fig. 7B). Danian mesophylls span a wide range of morphologically diverse lobed, unlobed, entire-margined, and toothed morphotypes. Mesophyll Maastrichtian morphotypes are generally entire-margined and share self-similar secondary venation patterns (e.g., labels 5 and 6, Fig. 9C).

We found distinct morphospaces occupied by lobed versus unlobed species, whether we included all species (Fig. 10A), Maastrichtianonly (Fig. 10B), or Danian-only (Fig. 10C) assemblages. Lobed leaves are consistently more morphologically disparate than unlobed types (Fig. 10B,C), a notable result considering that presence of lobes is only one of the more than 40 characters weighted equally in the ordination. Lobation in Danian species is generally associated with non-entire margins and craspedodromous venation, a relatively uncommon combination in Maastrichtian assemblages.

Regarding margin characters, in both Maastrichtian and Danian assemblages, toothed and entire-margined morphotypes occupy distinct morphospaces (Fig. 10D), presumably in large part a result of the numerous characters in the matrix that pertain to toothed margins that are coded as zeroes for entire-margined morphotypes. However, there is some overlap among toothed and entire-margined types in Maastrichtian assemblages, characterized by species with margins scored as crenate and a few entire-margined examples (Fig. 10E). Interestingly, there is no such overlap in Danian assemblages (Fig. 10F), graphically showing the loss of crenate margins from pre- to post- $\mathrm{K} / \mathrm{Pg}$ assemblages and indicating one of the few morphological losses.

Pollen Analysis and Floral Heterogeneity among Sections.-Comparison of published pollen records from the same sections as the macrofloral localities (Fig. 1D) shows that the Maastrichtian-Danian Lefipán and Danian-only Salamanca Formation samples (Fig. 1A) share most of the same pollen species and thus the same higher taxa (families and possibly genera), whether or not the Maastrichtian pollen data are included. First, in the closest 
- Maastrichtian species $\Delta$ Danian species
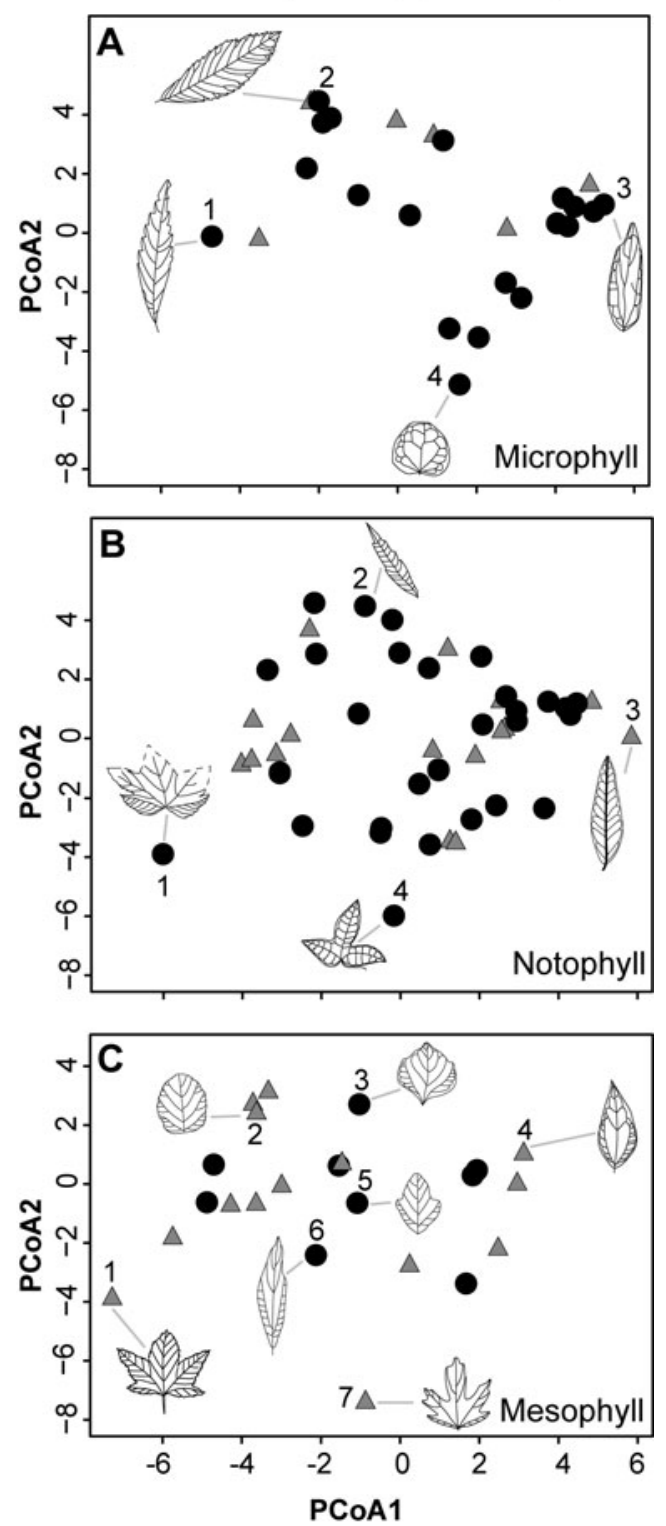

FIGURE 9. Morphospace occupation (axis 2 vs. axis 1) partitioned by maximum leaf size per species using the same PCoA scores for each species shown in Fig. 8. Microphyll is the smallest size class present; mesophyll is the largest. A, Microphylls, selected end-member morphotypes with icons are 1, LEF16; 2, LEF20; 3, LEF46; 4, LEF34. B, Notophylls, examples are 1, LEF64; 2, LEF01; 3, SA50; 4, LEF05. C, Mesophylls, examples are 1, SA35; 2, SA74; 3, LEF12; 4, SA73; 5, LEF07; 6, LEF26; 7, SA55.

stratigraphic comparison with the leaf data, approximately $60 \%$ of palynospecies in the Danian Salamanca Formation are shared with the Maastrichtian part of the Lefipán Formation
(Supplementary Table 2). Second, the Salamanca Formation also shares about $75 \%$ of palynospecies with the Danian strata of the Lefipán (Barreda et al. 2012; Supplementary Table 2). Thus, the same higher plant taxa are inferred to be present in the Danian microfloras of both formations (Fig. 1), despite the high species-level turnover indicated by leaves. Third, the percentage of shared palynotaxa among the Maastrichtian Lefipán and the Danian Salamanca (i.e., the pollen analog to the macrofloras studied here; Fig. 1) is similar to that among Maastrichtian and Danian Lefipán Formation samples within the SRS.

These palynological results all suggest that geographic separation does not significantly influence the composition of higher taxa between the two localities, supporting the comparability of the Maastrichtian and Danian macrofloras undertaken here. Considering all the Danian palynotaxa (Lefipán and Salamanca), $80 \%$ are Cretaceous-Paleogene survivors based on the Cretaceous Lefipán as the source of survivors for both formations, demonstrating the persistence of taxa including the gymnosperm families Podocarpaceae and Classopollis sp. (Cheirolepidiaceae) and the angiosperm families Arecaceae, Liliaceae, Proteaceae, Symplocaceae, and Gunneraceae, as well as various bryophytes and ferns (Supplementary Tables 1,2). Cluster analysis of the Beals smoothed compositional matrix (Fig. 11) shows that despite the high percentage of palynomorph species shared between the two formations, compositional differences associated with age and formation can be recognized.

\section{Discussion}

A high angiosperm macrofloral extinction percentage, drop in rarefied species richness, depauperate and homogeneous early Paleocene floras (Fig. 6) despite spanning a range of continental to marginal facies (e.g., Comer et al. 2015), and significant extinction of specialized plant-insect associations in Patagonia (Donovan et al. 2016) all provide evidence of a significant $\mathrm{K} / \mathrm{Pg}$ floral extinction event as seen in NAM (Fig. 5) (Wolfe and Upchurch 1986; Johnson and Hickey 1990; Johnson 2002; Wilf and Johnson 2004). Our results support a 

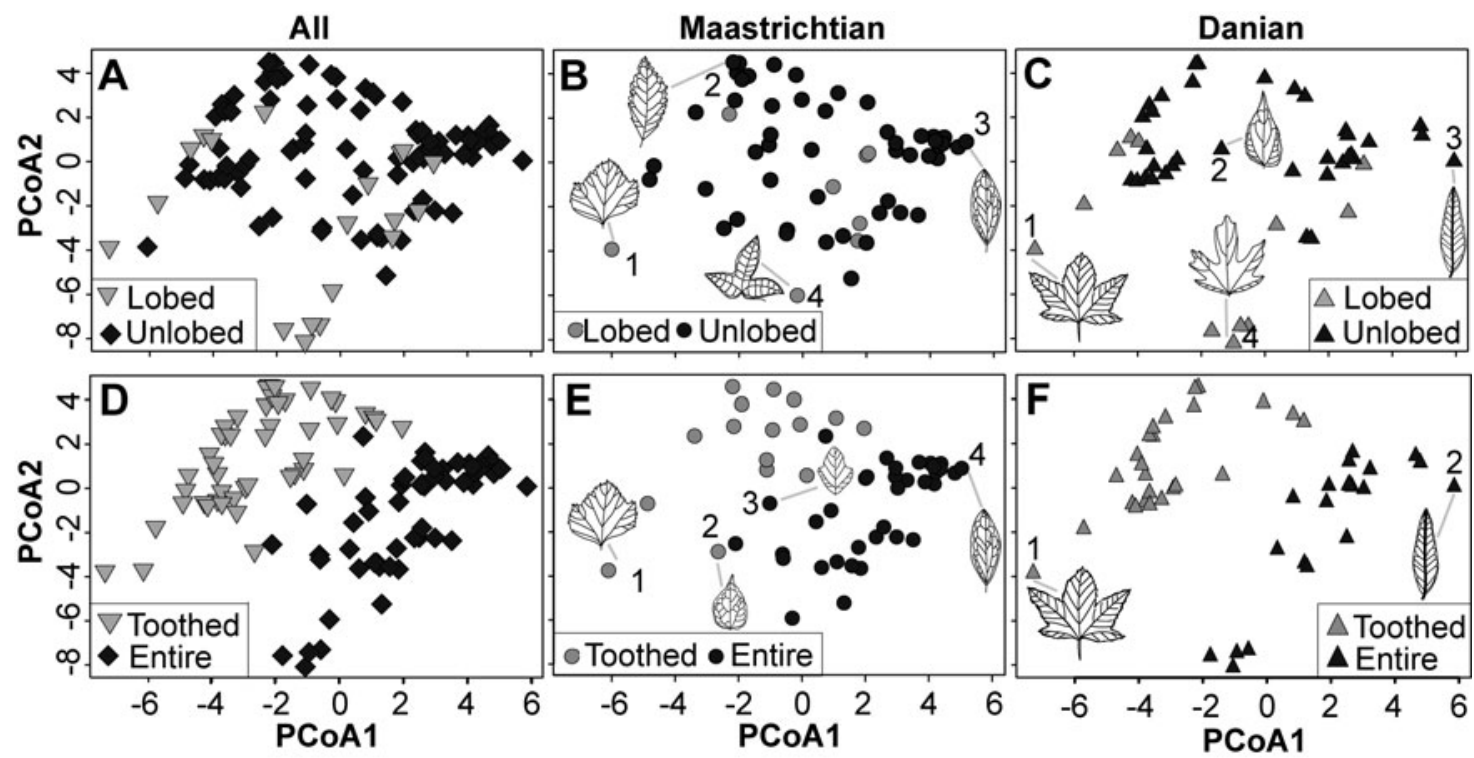

FIGURE 10. Principal coordinates analysis (PCoA axis 2 vs. axis 1) coded by time period, lobed vs. unlobed species (A-C), and toothed vs. entire-margined species (D-F). Species ordination scores are the same as and extracted from the analysis shown in Fig. 8. A-C, Lobed species lead the morphospace increase from Maastrichtian to Danian assemblages. D-F, Toothed and entire-margined species occupy distinct areas of morphospace in all assemblages and increase in separation in Danian assemblages, indicating a loss of intermediate morphospace across the extinction interval. First column shows morphospace occupation by all species, colored by respective character. Second column shows morphospace distribution of Maastrichtian species only. Exemplars in B, 1, LEF64; 2, LEF66; 3, LEF46; 4, LEF05; and E, 1, LEF64; 2, LEF53; 3, LEF7; 4, LEF46. Third column shows morphospace distribution of Danian species only. Exemplars in C, 1, SA35; 2, SA48; 3, SA50; 4, SA39; and F, 1, SA35; 2, SA50.

disruption in plant communities of global extent across the K/Pg (Vajda et al. 2001; Nichols and Johnson 2008; Barreda et al. 2012; Cantrill and Poole 2012; Vajda and Bercovici 2014; Donovan et al. 2016).

Lauraceae have recently been proposed as the principal component of $\mathrm{K} / \mathrm{Pg}$ recovery macrofloras alongside the classic fern spike in the North American Ratón Basin (Berry 2019), although Lauraceae are not reported from the well-sampled early Danian localities in North Dakota (Johnson 2002). The dominance of L. piatnitzkyi in early Paleocene Patagonian macrofloras, and of several other leaf morphotypes assigned to the family (Iglesias 2007; Iglesias et al. 2007) would be consistent with the presence of Lauraceae-dominated $\mathrm{K} / \mathrm{Pg}$ recovery floras in regions of both North and South America.

Despite the similarities between Patagonian and North American records, the subtle differences between them suggest that extinction could have been heterogeneous between the two regions. Morphological turnover shows interesting differences between the WB and Patagonia, even though the WB floras have not been analyzed in morphospace. Maastrichtian assemblages of North Dakota are characterized by the abundance of leaves with a "Cretaceous look" or unusual lobation (Johnson 2002: p. 371), a feature that is drastically reduced in the early Paleocene (Johnson and Hickey 1990; Johnson 2002). In contrast, the increase in proportion of lobed and toothed species in the early Paleocene of Patagonia (Fig. 8) (Iglesias et al. 2007) leads to an expansion in morphospace occupation by post- $\mathrm{K} / \mathrm{Pg}$ assemblages. Despite our estimate of almost complete species-level macrofloral turnover in Patagonia, the continuity and expansion of leaf morphologies (Fig. 8) and, presumably, their underlying ecological and phylogenetic diversity across the $\mathrm{K} / \mathrm{Pg}$ could, in part, reflect low turnover at higher taxonomic levels observed in both the microfloral and macrofloral records of Patagonia (Barreda et al. 2012; Supplementary Table 1). 


\section{A All species}

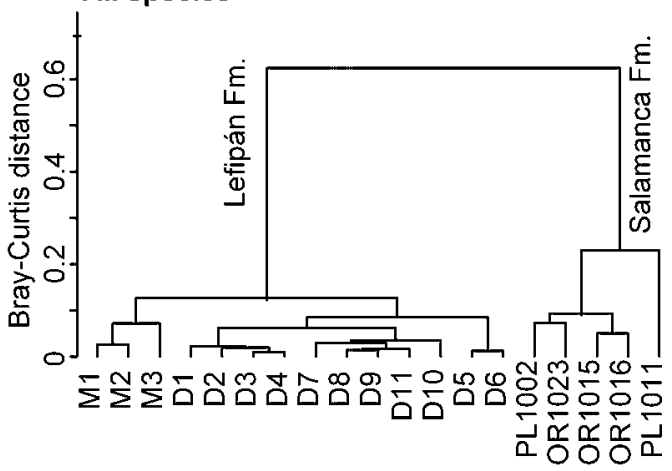

B Gymnosperms and angiosperms

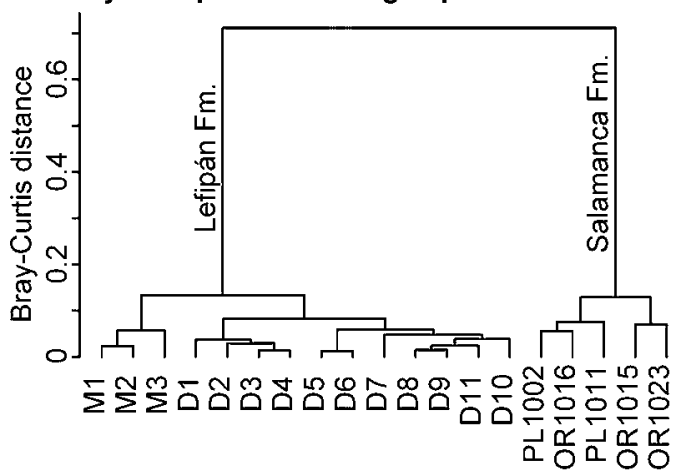

C Angiosperms

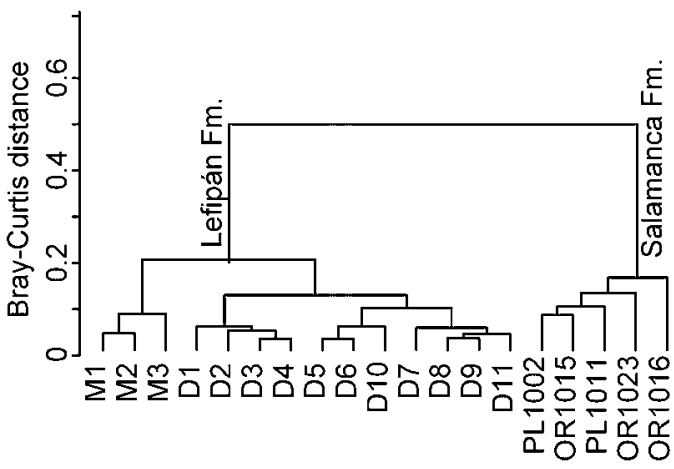

FIGURE 11. Cluster analyses of palynospecies occurrences with Beals smoothing (see "Methods" and Fig. 1) from the Maastrichtian (samples M1-3) and Danian (D1-11) Lefipán Fm. (Barreda et al. 2012) and Danian-only Salamanca Fm. (remaining samples; Fig. 1) (Clyde et al. 2014). A, All species. $\mathrm{B}$, Gymnosperms and angiosperms only. C, Angiosperms only.

Both WB and Patagonian species richness suffer a sharp drop between Maastrichtian and Danian assemblages (Fig. 5). The $\mathrm{K} / \mathrm{Pg}$ drop in rarefied species richness, though severe in both areas, is much sharper in the WB (ca. $75 \%$ ) than in Patagonia (ca. 45\%; Fig. 5). Rarefaction highlights another important contrast between the WB and Patagonian records; not only Danian (Iglesias et al. 2007) but also Maastrichtian assemblages in Patagonia are significantly more diverse than coeval macrofloras in the WB. The Lefipán floras are approximately $40 \%$ richer than the most diverse Maastrichtian Hell Creek (HCIII) NAM zone assemblage (Fig. 5). Thus, whereas previous studies of the Danian Salamanca Formation (Iglesias 2007; Iglesias et al. 2007) and Eocene macrofloras of Patagonia (Wilf et al. 2003a, 2005) provided evidence for an ancient history of high South American Cenozoic floral diversity, our results (Fig. 5) extend that history into the Late Cretaceous.

The high species richness of Patagonian Paleocene and Eocene assemblages compared with NAM equivalents has been hypothesized in part to be the legacy of low $\mathrm{K} / \mathrm{Pg}$ floral extinction as observed in the palynological record (Barreda et al. 2012). Our results suggest that the rich Cenozoic macrofloras of Patagonia also carry a legacy of rich Cretaceous floras, as well as significantly earlier recovery of Paleocene species richness resulting from the persistence of most higher taxonomic levels (Supplementary Tables 1, 2). Nonetheless, an emerging body of research shows that floral diversity in the early Paleocene of the Denver and San Juan Basins can be higher relative to the more northerly WB (Johnson and Ellis 2002; Flynn and Peppe 2019; Lyson et al. 2019). These studies show heterogeneity in NAM floral richness during the early Paleocene, a pattern warranting further intensive study.

Insect damage-type data on the same leaf collections studied here showed a similar pattern of high extinction and robust early recovery compared with NAM (Donovan et al. 2016, 2018). Donovan et al. $(2016,2018)$ posed the disappearance of plant hosts across the K/ $\mathrm{Pg}$ as a potential driving mechanism for the severe insect herbivore extinction observed in Patagonia; host-specialized insects such as leaf miners would have been severely affected by an elevated species-level floral extinction (as in NAM: Labandeira et al. 2002; Donovan et al. 2014). Our results confirm this interpretation and suggest that despite the low $\mathrm{K} / \mathrm{Pg}$ turnover of major clades observed in floras of 
Patagonia and elsewhere (see Sauquet and Magallón 2018), high plant-species turnover resulted in devastating consequences for terrestrial faunas.

The empirical species-extinction percentage of $>90 \%$ in Patagonia in all likelihood is positively biased by several factors, including coarser stratigraphic sampling than in WB macrofloras, geographic variation, and climatic effects, and that is why we present it as a maximum estimate. Regarding sampling, the uncertain temporal placement of the Lefipán Formation macrofloras within the last ca. million years before the $\mathrm{K} / \mathrm{Pg}$ boundary (Barreda et al. 2012; Vellekoop et al. 2017) and the lack of earliest Danian (chron 29r) sediments preserved in the Salamanca Formation probably bias against finding a higher number of survivor pairs (Fig. 1). The limited stratigraphic coverage of macrofloras in the upper Lefipán Formation is analogous to considering only a small interval of the Hell Creek Formation (Johnson et al. 1989; Johnson 2002; Wilf and Johnson 2004), where there is a general trend of lower percentages of observed survivor dicot-leaf species in a simple experiment where the distance of sample windows below the boundary layer increases (Fig. 12). Furthermore, observed extinction may exceed 90\% even for some intervals relatively close to the boundary, as can be seen in the $20-30 \mathrm{~m}$ and $40-50 \mathrm{~m}$ bins of the Hell Creek Formation (Fig. 12). Although there are macrofloral collections from lower Lefipán Formation strata (Andruchow-Colombo et al. 2018; Martínez et al. 2018), their precise age is not known, and the preserved diversity of dicot leaves is not nearly so extensive as in the upper Lefipán studied here. Therefore, observations across a wide stratigraphic range in the Lefipán Formation are not possible at this time.

Addressing the geographic separation between the Maastrichtian and Danian macrofloras (Fig. 1), the cluster results showing differences between the Lefipán and Salamanca sections' microfloral assemblages (Fig. 11) provide evidence for some geographical heterogeneity of higher-taxa associations, which would accentuate species-level contrasts observed in the respective macrofloras (Behrensmeyer et al. 2000; Nichols and Johnson 2008). Different

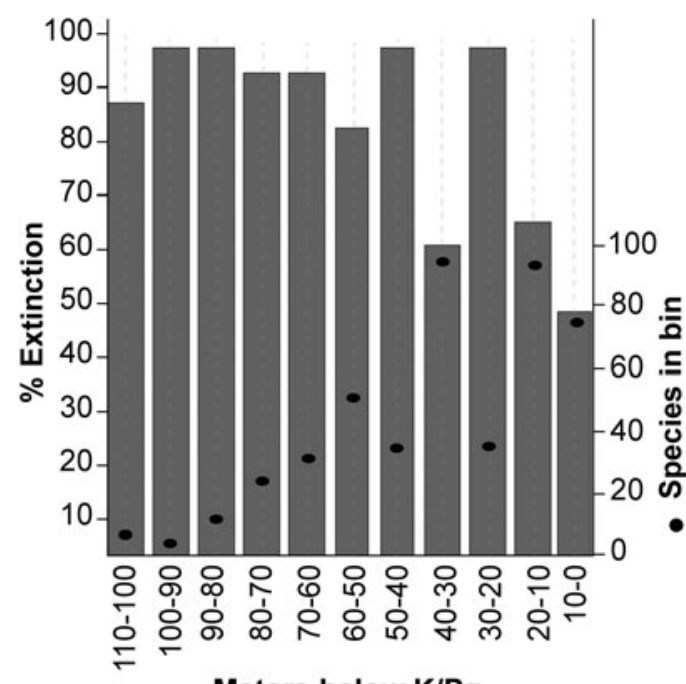

FIGURE 12. Simulated percentage of $\mathrm{K} / \mathrm{Pg}$-surviving Cretaceous dicot-leaf species in the Williston Basin of North Dakota by $10 \mathrm{~m}$ bin window below the $\mathrm{K} / \mathrm{Pg}$ impact horizon (data from Wilf and Johnson [2004], including singletons; see "Discussion" for details). The Lefipán leaf floras studied here, with a $91 \%$ observed extinction, could correlate temporally to any one of these stratigraphic bins.

underlying palynospecies associations suggest that the $400 \mathrm{~km}$ spatial separation of Maastrichtian and Danian assemblages plays some role in the likely overestimation of Patagonian macrofloral extinction by imparting a geographical bias (Fig. 11). On the other hand, geographic effects could not have been severe, because the number of shared palynospecies in the same strata as the leaf floras was very high (see "Results").

With regard to climate, marine and continental proxy records show a global relatively shortlived climatic warming within the last ca. 500 kyr of the Maastrichtian, followed by cooling during the final ca. 100 kyr of the Maastrichtian persisting into the early Paleocene (Stott et al. 1990; Huber and Watkins 1992; Wilf et al. 2003b; Bowman et al. 2014; Vellekoop et al. 2017; Woelders et al. 2017; Huber et al. 2018; Hull et al. 2020). The increase in toothed and lobed leaf morphotypes across the $\mathrm{K} / \mathrm{Pg}$ in Patagonia $(39.7 \%$ to $60.5 \%$ and $12 \%$ to $27.9 \%$, respectively), both of which are observed drivers of morphospace expansion in Paleogene floras, would correlate to a ca. $5^{\circ} \mathrm{C}$ drop in mean annual temperature, with standard caveats for paleoclimatic inference on this 
basis (Wolfe 1971; Greenwood et al. 2004; Little et al. 2010). The uncertain age within the last million years of the Maastrichtian of the Lefipán Formation macrofloras studied here, however, introduces an important potential climatic bias on observed extinction that would compound the sampling bias mentioned earlier.

In the Hell Creek Formation, peak richness of floral diversity (HCIII zone flora) correlates with the highest temperature estimates of the late Maastrichtian, followed by a decline in species richness during rapid cooling in the terminal Maastrichtian (Wilf et al. 2003b). If a comparison were to be made solely between a collection of Maastrichtian HCIII floras from the peak of diversity of warmth and those of the Fort Union, an overestimation of extinction percentages would result. For example, if we only compare the $-15 \mathrm{~m}$ (HCIII) and $+38 \mathrm{~m}$ (in C29N like the PL1 flora) horizons in North Dakota (Wilf et al. 2003b; Wilf and Johnson 2004), the observed dicot-leaf extinction is $99 \%$. Although it is not possible to state the age of the Maastrichtian Lefipán Formation floras at this precision, their high species richness, dinoflagellate markers indicative of the last 0.5 Myr of the Cretaceous, and associated warm proxy temperatures (Barreda et al. 2012; Scasso et al. 2012; Vellekoop et al. 2017) suggest that they could correlate to the terminal Cretaceous warming event and thus HCIII, possibly translating into an overestimation of macrofloral extinction in this study on the assumption that temperature correlates with plant diversity.

\section{Conclusions}

We report the first $\mathrm{K} / \mathrm{Pg}$ macrofloral investigation in the Southern Hemisphere that is based on large, stratigraphically constrained collections. Our 92\% observed macrofloral extinction is best viewed as a maximum because of likely geographic, stratigraphic, and paleoclimatic biases. Nonetheless, our estimate clearly reflects underlying high species-level turnover in Patagonia. High macrofloral turnover and associated insect herbivore extinction, compositionally homogeneous Danian floras, and a sharp drop in rarefied floral species richness in Patagonia reveal extinction and recovery patterns broadly resembling those observed in NAM and support a geographically widespread extinction event. However, Patagonian and North American turnover show contrasts.

Compared with NAM floras of the WB in North Dakota, Patagonian floras are much more diverse in both Maastrichtian (Fig. 5) and Danian (Iglesias et al. 2007) assemblages. Richer Maastrichtian floras in Patagonia may have contributed to the less severe drop in overall species richness and significantly faster Danian recovery than observed in the WB or other northern Great Plains floras. Insect herbivory observations on the same collections (Donovan et al. 2016, 2018) follow patterns similar to North American records, indicating that the macrofloral species extinction in Patagonia had catastrophic effects on herbivorous insect communities. However, like their host macrofloras, specialized insect damage types in Patagonia recover much faster than those in NAM, despite high turnover in both regions.

This study reports speciose Maastrichtian macrofloras in Patagonia for the first time, extending the history of elevated floral diversity in South America into the terminal Cretaceous. The limited palynological extinction and continuity of most higher taxa (families and genera) across time and space indicate persistence of major plant clades even as significant extinction took place at the species level. Leaves with lauraceous affinity are characteristically dominant in the Patagonian macrofloral assemblages, as in the NAM Ratón Basin, drawing an interesting parallel between the two regions. In addition to Lauraceae, we provide macrofloral evidence to support the survival of the families Cunoniaceae, Malvaceae, and Rosaceae in Patagonia.

Morphospace analysis of MaastrichtianDanian Patagonian macrofloras shows minimal character loss from the $\mathrm{K} / \mathrm{Pg}$ extinction and that Danian macrofloras are morphologically more diverse than Maastrichtian assemblages. Danian floras rich in lobed and toothed species appear to be a notable Patagonian characteristic that contrasts with North American macrofloras of the WB, where lobed forms largely disappear across the $\mathrm{K} / \mathrm{Pg}$. Increased diversity of toothed species in Danian Patagonian 
assemblages is probably related to a general climatic cooling, potentially aligning with global temperature records.

Extinction and recovery in Patagonian macrofloras parallel North American WB assemblages in the $\mathrm{K} / \mathrm{Pg}$ drop of rarefied species richness, low-diversity homogeneous Paleocene floras, and dramatic loss of specialized insect herbivores, indicating that terrestrial ecosystems in both areas were severely disrupted. Contrasts between Patagonian and North American macrofloras emerge in a faster Patagonian recovery, comparably much higher floral diversity throughout the Cretaceous-Paleogene time interval, and differences in morphological turnover.

\section{Acknowledgments}

We thank the technical staff of the Museo Paleontológico Egidio Feruglio (MEF), including P. Puerta, M. Caffa, E. Ruigomez, L. Reiner, and L. Canessa, as well as K. Johnson, R. Scasso, M. Donovan, and many others for their field and laboratory assistance over several expeditions and collections visits. We thank V. Barreda for her assistance reviewing palynological records and M. Patzkowsky and T. Bralower for valuable advice during the development of this project. We thank the editors, K. Boyce and C. Looy, and V. Vajda and three anonymous reviewers for providing constructive feedback that helped us improve this article. Funding was provided to E.S. by Geological Society of America Student Research grant no.12008-18, a Mid-American Paleontological Society (MAPS) Outstanding Research Award, the Penn State Geosciences Charles E. Knopf, Sr., Memorial Scholarship, and two Penn State Geosciences Paul D. Krynine Scholarships, as well as contributions from National Science Foundation grants DEB-15556666/1556136, EAR-1925755/1925552, DEB-0919071/0918932, and DEB-0345750 that benefited all authors. This work partially fulfilled the M.Sc. in Geosciences degree requirements of E.S. at Penn State University.

\section{Literature Cited}

Aberhan, M., and W. Kiessling. 2014. Rebuilding biodiversity of Patagonian marine molluscs after the end-Cretaceous mass extinction. PLoS ONE 9:e102629.
Alvarez, L. W., W. Alvarez, F. Asaro, and H. V. Michel. 1980. Extraterrestrial cause for the Cretaceous-Tertiary extinction. Science 208:1095-1108.

Alvarez, W., F. Asaro, and A. Montanari. 1990. Iridium profile for 10 million years across the Cretaceous-Tertiary boundary at Gubbio (Italy). Science 250:1700-1702.

Andruchow-Colombo, A., I. H. Escapa, N. R. Cúneo, and M. A. Gandolfo. 2018. Araucaria lefipanensis (Araucariaceae), a new species with dimorphic leaves from the Late Cretaceous of Patagonia, Argentina. American Journal of Botany 105:1067-1087.

Andruchow-Colombo, A., I. H. Escapa, R. J. Carpenter, R. S. Hill, A. Iglesias, A. M. Abarzua, and P. Wilf. 2019. Oldest record of the scale-leaved clade of Podocarpaceae, early Paleocene of Patagonia, Argentina. Alcheringa 43:127-145.

Aragón, E., and M. M. Mazzoni. 1997. Geología y estratigrafía del complejo volcánico piroclástico del Rio Chubut. Revista de la Asociación Geológica Argentina 52:243-256.

Aragón, E., A. Castro, J. Diaz-Alvarado, L. Pinotti, F. D’Eramo, M. Demartis, J. Coniglio, I. Hernando, and C. Rodriguez. 2018. Mantle derived crystal-poor rhyolitic ignimbrites: eruptive mechanism from geochemical and geochronological data of the Piedra Parada caldera, Southern Argentina. Geoscience Frontiers 9:1529-1553.

Archangelsky, S. 1973. Palinología del Paleoceno de Chubut. I. Descripciones sistemáticas. Ameghiniana 10:339-399.

Artemieva, N., and J. Morgan. 2017. Quantifying the release of climate-active gases by large meteorite impacts with a case study of Chicxulub. Geophysical Research Letters 44:10-180.

Ash, A., B. Ellis, L. J. Hickey, K. R. Johnson, P. Wilf, and S. L. Wing. 1999. Manual of leaf architecture-morphological description and categorization of dicotyledonous and net-veined monocotyledonous angiosperms. Smithsonian Institution, Washington D.C.

Baldoni, A. M. 1992. Palynology of the lower Lefipán Formation (Upper Cretaceous) of Barranca de los Perros, Chubut Province, Argentina. Part I. Cryptogam spores and gymnosperm pollen. Palynology 16:117-136.

Baldoni, A. M., R. A. Askin, and A. M. Baldoni. 1993. Palynology of the lower Lefipán Formation (Upper Cretaceous) of Barranca de los Perros, Chubut Province, Argentina Part II. Angiosperm pollen and discussion. Palynology 17:241-264.

Barclay, R. S., K. R. Johnson, W. J. Betterton, and D. L. Dilcher. 2003. Stratigraphy and megaflora of a K-T boundary section in the eastern Denver Basin, Colorado. Rocky Mountain Geology 38:45-71.

Bardeen, C. G., R. R. Garcia, O. B. Toon, and A. J. Conley. 2017. On transient climate change at the Cretaceous-Paleogene boundary due to atmospheric soot injections. Proceedings of the National Academy of Sciences USA 114:7415-7424.

Barreda, V. D., N. R. Cúneo, P. Wilf, E. D. Currano, R. A. Scasso, and H. Brinkhuis. 2012. Cretaceous/Paleogene floral turnover in Patagonia: drop in diversity, low extinction, and a Classopollis spike. PLoS ONE 7:e52455.

Behrensmeyer, A. K., S. M. Kidwell, and R. A. Gastaldo. 2000. Taphonomy and paleobiology. Paleobiology 26:103-147.

Bercovici, A., D. Pearson, D. Nichols, and J. Wood. 2009. Biostratigraphy of selected K/T boundary sections in southwestern North Dakota, USA: toward a refinement of palynological identification criteria. Cretaceous Research 30:632-658.

Berry, E. W. 1937. Succession of fossil floras in Patagonia. Proceedings of the National Academy of Sciences USA 23:537-542.

Berry, K. 2019. Linking fern foliage with spores at the K-Pg boundary section in the Sugarite coal zone, New Mexico, USA, while questioning the orthodoxy of the global pattern of plant succession across the K-Pg boundary. Neues Jahrbuch für Geologie und Paläontologie-Abhandlungen 291:159-169.

Bonaparte, J. F., L. M. Van Valen, and A. Kramartz. 1993. La fauna local de Punta Peligro, Paleoceno Inferior, de la provincia del Chubut, Patagonia, Argentina. Evolutionary Monographs 14:1-61. 
Bowman, V. C., J. E. Francis, R. A. Askin, J. B. Riding, and G. T. Swindles. 2014. Latest Cretaceous-earliest Paleogene vegetation and climate change at the high southern latitudes: palynological evidence from Seymour Island, Antarctic Peninsula. Palaeogeography, Palaeoclimatology, Palaeoecology 408:26-47.

Brea, M., S. D. Matheos, A. Zamuner, and D. Ganuza. 2005. Análisis de los anillos de crecimiento del bosque fósil de Victor Szlápelis, Terciario Inferior del Chubut, Argentina. Ameghiniana 42:407-418.

Brooks, R. R., C. P. Strong, J. Lee, C. J. Orth, J. S. Gilmore, D. E. Ryan, and J. Holzbecher. 1986. Stratigraphic occurrences of iridium anomalies at four Cretaceous/Tertiary boundary sites in New Zealand. Geology 14:727-729.

Brugger, J., G. Feulner, and S. Petri. 2017. Baby, it's cold outside: climate model simulations of the effects of the asteroid impact at the end of the Cretaceous. Geophysical Research Letters 44:419-427.

Burnham, R. J. 1993. Reconstructing richness in the plant fossil record. Palaios 8:376-384.

Butler, K. L., B. K. Horton, A. Echaurren, A. Folguera, and F. Fuentes. 2019. Cretaceous-Cenozoic growth of the Patagonian broken foreland basin, Argentina: chronostratigraphic framework and provenance variations during transitions in Andean subduction dynamics. Journal of South American Earth Sciences 97:102242.

Cantrill, D. J., and Poole, I. 2012. The origin of southern temperate ecosystems. Pp. 249-307 in D. J. Cantrill and I. Poole, eds. The vegetation of Antarctica through geological time. Cambridge University Press, Cambridge.

Carpenter, R. J., A. Iglesias, and P. Wilf. 2018. Early Cenozoic vegetation in Patagonia: new insights from organically preserved plant fossils (Ligorio Márquez Formation, Argentina). International Journal of Plant Sciences 179:115-135.

Casal, G. A., Allard, J. O., and Foix, N., 2015, Análisis estratigráfico y paleontológico del Cretácico superior en la cuenca del golfo San Jorge: nueva unidad litoestratigráfica para el Grupo Chubut. Revista de la Asociación Geológica Argentina 72:77-95.

Case, J. A., and M. O. Woodburne. 1986. South American marsupials: a successful crossing of the Cretaceous-Tertiary boundary. Palaios 1:413-416.

Clyde, W. C., P. Wilf, A. Iglesias, R. L. Slingerland, T. Barnum, P. K. Bijl, T. J. Bralower, H. Brinkhuis, E. E. Comer, B. T. Huber, M. Ibañez-Mejia, B. R. Jicha, J. M. Krause, J. D. Schueth, B. S. Singer, M. S. Raigemborn, M. D. Schmitz, A. Sluijs, and M. C. Zamaloa. 2014. New age constraints for the Salamanca Formation and lower Río Chico Group in the western San Jorge Basin, Patagonia, Argentina: implications for Cretaceous-Paleogene extinction recovery and land mammal age correlations. Geological Society of America Bulletin 126:289-306.

Comer, E. E., R. L. Slingerland, J. M. Krause, A. Iglesias, W. C. Clyde, M. S. Raigemborn, and P. Wilf. 2015. Sedimentary facies and depositional environments of diverse early Paleocene floras, north-central San Jorge Basin, Patagonia, Argentina. Palaios 30:553-573.

Donovan, M. P., P. Wilf, C. C. Labandeira, K. R. Johnson, and D. J. Peppe. 2014. Novel insect leaf-mining after the end-Cretaceous extinction and the demise of Cretaceous leaf miners, Great Plains, USA. PLoS ONE 9:e103542.

Donovan, M. P., A. Iglesias, P. Wilf, C. C. Labandeira, and N. R. Cúneo. 2016. Rapid recovery of Patagonian plant-insect associations after the end-Cretaceous extinction. Nature Ecology \& Evolution 1:0012.

Donovan, M. P., A. Iglesias, P. Wilf, C. C. Labandeira, and N. R. Cúneo. 2018. Diverse plant-insect associations from the latest Cretaceous and early Paleocene of Patagonia, Argentina. Ameghiniana 55:303-338.

Ellis, B., D. C. Daly, L. J. Hickey, K. R. Johnson, J. D. Mitchell, P. Wilf, and S. L. Wing. 2009. Manual of leaf architecture. Cornell University Press, Ithaca, N.Y.
Erwin, D. H. 2002. Lessons from the past: biotic recoveries from mass extinctions. Proceedings of the National Academy of Sciences USA 98:5399-5403.

Escapa, I. H., A. Iglesias, P. Wilf, S. A. Catalano, M. A. Caraballo-Ortiz, and N. Rubén Cúneo. 2018. Agathis trees of Patagonia's Cretaceous-Paleogene death landscapes and their evolutionary significance. American Journal of Botany 105:1345-1368.

Figari, E. G., R. A. Scasso, N. R. Cúneo, and I. H. Escapa. 2015. Estratigrafía y evolución geológica de la Cuenca de Cañadón Asfalto, Provincia del Chubut, Argentina. Latin American Journal of Sedimentology and Basin Analysis 22:135-169.

Flynn, A. G., and D. J. Peppe. 2019. Early Paleocene tropical forest from the Ojo Alamo Sandstone, San Juan Basin, New Mexico, USA. Paleobiology 45:612-635.

Foote, M. 1993. Discordance and concordance between morphological and taxonomic diversity. Paleobiology 19:185-204.

Foote, M. 1994. Morphological disparity in Ordovician-Devonian crinoids and the early saturation of morphological space. Paleobiology 20:320-344.

Futey, M. K., M. A. Gandolfo, M. C. Zamaloa, R. Cúneo, and G. Cladera. 2012. Arecaceae fossil fruits from the Paleocene of Patagonia, Argentina. Botanical Review 78:205-234.

Gelfo, J. N., F. J. Goin, M. O. Woodburne, and C. D. E. Muizon. 2009. Biochronological relationships of the earliest South American Paleogene mammalian faunas. Palaeontology 52:251-269.

Gerber, S. 2019. Use and misuse of discrete character data for morphospace and disparity analyses. Palaeontology 62:305-319.

Givnish, T. J., and R. Kriebel. 2017. Causes of ecological gradients in leaf margin entirety: evaluating the roles of biomechanics, hydraulics, vein geometry, and bud packing. American Journal of Botany 104:354-366.

Goin, F. J., R. Pascual, M. F. Tejedor, J. N. Gelfo, M. O. Woodburne, J. A. Case, M. A. Reguero, M. Bond, G. M. López, A. L. Cione, D. U. Sauthier, L. Balarino, R. A. Scasso, F. A. Medina, and M. C. Ubaldón. 2006. The earliest Tertiary therian mammal from South America. Journal of Vertebrate Paleontology 26:505-510.

Goin, F. J., M. F. Tejedor, L. Chornogubsky, M. López, J. N. Gelfo, and M. O. Woodburne. 2012. Persistence of a Mesozoic, nontherian mammalian lineage (Gondwanatheria) in the midPaleogene of Patagonia. Naturwissenschaften 99:449-463.

Gradstein, F. M., Ogg, J. G., Schmitz, M. D., and Ogg, G., eds. 2012, The geologic time scale 2012. Elsevier, Amsterdam, Netherlands.

Greenwood, D. R., S. L. Wing, and D. C. Christophel. 2004. Paleotemperature estimation using leaf margin analysis: is Australia different? Palaios 19:129-142.

Hickey, L. J., and J. A. Wolfe. 1975. The bases of angiosperm phylogeny: vegetative morphology. Annals of the Missouri Botanical Garden 62:538-589.

Hicks, J. F., K. R. Johnson, J. D. Obradovich, L. Tauxe, and D. P. Clark. 2002. Magnetostratigraphy and geochronology of the Hell Creek and basal Fort Union formations of southwestern North Dakota and a recalibration of the age of the CretaceousTertiary boundary. Geological Society of America Special Paper 361:35-55.

Hotton, C. L. 2002. Palynology of the Cretaceous-Tertiary boundary in central Montana: evidence for extraterrestrial impact as a cause of the terminal Cretaceous extinctions. Geological Society of America Special Paper 361:473-501.

Hsieh, T. C., K. H. Ma, and A. Chao. 2016. iNEXT: an R package for rarefaction and extrapolation of species diversity (Hill numbers). Methods in Ecology and Evolution 7:1451-1456.

Huber, B. T., and D. K. Watkins. 1992. Biogeography of Campanian-Maastrichtian calcareous plankton in the region of the Southern Ocean: paleogeographic and paleoclimatic implications. Antarctic Research Series 56:31-60. 
Huber, B. T., K. G. MacLeod, D. K. Watkins, and M. F. Coffin. 2018. The rise and fall of the Cretaceous hot greenhouse climate. Global and Planetary Change 167:1-23.

Hull, P. M., A. Bornemann, D. E. Penman, M. J. Henehan, R. D. Norris, P. A. Wilson, P. Blum, L. Alegret, S. J. Batenburg, P. R. Bown, T. J. Bralower, C. Cournede, A. Deutsch, B. Donner, O. Friedrich, S. Jehle, H. Kim, D. Kroon, P. Lippert, D. Loroch, I. Moebius, K. Moriya, D. Peppe, G. E. Ravizza, U. Röhl, J. Schueth, J. Sepúlveda, P. Sexton, E. Sibert, K. Sliwinska, R. E. Summons, E. Thomas, T. Westerhold, J. H. Whiteside, T. Yamaguchi, and J. C. Zachos. 2020. On impact and volcanism across the Cretaceous-Paleogene boundary. Science 367:266-272.

Iglesias, A. 2007. Estudio paleobotánico, paleoecológico y paleoambiental en secuencias de la Formación Salamanca, del Paleoceno Inferior en el sur de la Provincia de Chubut, Patagonia, Argentina. Ph.D. thesis, Universidad Nacional de La Plata, La Plata, Argentina.

Iglesias, A., P. Wilf, K. R. Johnson, N. R. Cúneo, and S. D. Matheos. 2007. A Paleocene lowland macroflora from Patagonia reveals significantly greater richness than North American analogs. Geology 35:947-950.

Jablonski, D. 2005. Mass extinctions and macroevolution. Paleobiology 31:192-210.

Jiang, S., T. J. Bralower, M. E. Patzkowsky, L. R. Kump, and J. D. Schueth. 2010. Geographic controls on nannoplankton extinction across the Cretaceous/Palaeogene boundary. Nature Geoscience 3:280-285.

Johnson, K. R. 1992. Leaf-fossil evidence for extensive floral extinction at the Cretaceous-Tertiary boundary, North Dakota, USA. Cretaceous Research 13:91-117.

Johnson, K. R. 2002. Megaflora of the Hell Creek and lower Fort Union formations in the Western Dakotas: vegetational response to climate change, the Cretaceous-Tertiary boundary event, and rapid marine transgression. Geological Society of America Special Paper 361:329-391.

Johnson, K. R., and B. Ellis. 2002. A tropical rainforest in Colorado 1.4 million years after the Cretaceous-Tertiary boundary. Science 296:2379-2383.

Johnson, K. R., and L. J. Hickey. 1990. Megafloral change across the Cretaceous/Tertiary boundary in the northern Great Plains and Rocky Mountains, U.S.A. Geological Society of America Special Paper 247:433-444.

Johnson, K. R., D. J. Nichols, M. Attrep, and C. J. Orth. 1989. Highresolution leaf-fossil record spanning the Cretaceous/Tertiary boundary. Nature 340:708-711.

Jud, N. A., M. A. Gandolfo, A. Iglesias, and P. Wilf. 2017. Flowering after disaster early Danian buckthorn (Rhamnaceae) flowers and leaves from Patagonia. PLoS ONE 12:e0176164.

Jud, N. A., M. A. Gandolfo, A. Iglesias, and P. Wilf. 2018a. Fossil flowers from the early Palaeocene of Patagonia, Argentina, with affinity to Schizomerieae (Cunoniaceae). Annals of Botany 121:431-442.

Jud, N. A., A. Iglesias, P. Wilf, and M. A. Gandolfo. 2018b. Fossil moonseeds from the Paleogene of west Gondwana (Patagonia, Argentina). American Journal of Botany 105:927-942.

Kennedy, E. M., R. A. Spicer, and P. M. Rees. 2002. Quantitative palaeoclimate estimates from Late Cretaceous and Paleocene leaf floras in the northwest of the South Island, New Zealand. Palaeogeography, Palaeoclimatology, Palaeoecology 184:321-345.

Krause, J. M., W. C. Clyde, M. Ibañez-Mejia, M. D. Schmitz, T. Barnum, E. S. Bellosi, and P. Wilf. 2017. New age constraints for early Paleogene strata of central Patagonia, Argentina: implications for the timing of South American Land Mammal Ages. Geological Society of America Bulletin 129:886-903.

Krug, A. Z., D. Jablonski, and J. W. Valentine. 2017. Signature of the end-Cretaceous mass extinction in the modern biota. Science 323:767-771.
Labandeira, C. C., K. R. Johnson, and P. Wilf. 2002. Impact of the terminal Cretaceous event on plant-insect associations. Proceedings of the National Academy of Sciences USA 99:2061-2066.

Legarreta, L., and M. A. Uliana. 1994. Asociaciones de fósiles y hiatos en el Supracretácico-Neógeno de Patagonia: una perspectiva estratigrafo-secuencial. Ameghiniana 31:257-281.

Lerbekmo, J. F., and R. M. St. Louis. 1986. The terminal Cretaceous iridium anomaly in the Red Deer Valley, Alberta, Canada. Canadian Journal of Earth Sciences 23:120-124.

Little, S. A., S. W. Kembel, and P. Wilf. 2010. Paleotemperature proxies from leaf fossils reinterpreted in light of evolutionary history. PLoS ONE 5:e15161.

Lyson, T. R., I. M. Miller, A. D. Bercovici, K. Weissenburger, A. J. Fuentes, W. C. Clyde, J. W. Hagadorn, M. J. Butrim, K. R. Johnson, R. F. Fleming, R. S. Barclay, S. A. Maccracken, B. Lloyd, G. P. Wilson, D. W. Krause, and S. G. B. Chester. 2019. Exceptional continental record of biotic recovery after the Cretaceous-Paleogene mass extinction. Science 983:977-983.

Martínez, C., M. A. Gandolfo, and N. R. Cúneo. 2018. Angiosperm leaves and cuticles from the uppermost Cretaceous of Patagonia, biogeographic implications and atmospheric paleo- $\mathrm{CO}_{2}$ estimates. Cretaceous Research 89:107-118.

McCune, B. 1994. Improving community analysis with the Beals smoothing function. Ecoscience 1:82-86.

McLoughlin, S., R. J. Carpenter, G. J. Jordan, and R. S. Hill. 2008. Seed ferns survived the end-Cretaceous mass extinction in Tasmania. American Journal of Botany 95:465-471.

McLoughlin, S., R. J. Carpenter, and C. Pott. 2011. Ptilophyllum muelleri (Ettingsh.) comb. nov. from the Oligocene of Australia. Last of the Bennettitales? International Journal of Plant Sciences 172:574-585.

Medina, F. A., and H. H. Camacho. 1990.Bioestratigrafía del Cretácico superior-Paleoceno marino de la Formación Lefipán, Barranca de los Perros, Río Chubut, Chubut. $V^{0}$ Congreso Argentino de Paleontología y Bioestratigrafía, Actas 7:137-142. San Miguel de Tucumán, Argentina.

Mitteroecker, P., and S. M. Huttegger. 2009. The concept of morphospaces in evolutionary and developmental biology: mathematics and metaphors. Biological Theory 4:54-67.

Münzbergová, Z., and T. Herben. 2004. Identification of suitable unoccupied habitats in metapopulation studies using co-occurrence of species. Oikos 105:408-414.

Nichols, D. J. 2002. Palynology and palynostratigraphy of the Hell Creek Formation in North Dakota: a microfossil record of plants at the end of Cretaceous time. Geological Society of America Special Paper 361:393-456.

Nichols, D. J., and R. F. Fleming. 1990. Plant microfossil record of the terminal Cretaceous event in the western United States and Canada. Geological Society of America Special Paper 247:445-469.

Nichols, D. J., and K. R. Johnson. 2008. Plants and the K-T boundary. Cambridge University Press, Cambridge.

Nichols, D. J., D. M. Jarzen, C. J. Orth, and P. Q. Oliver. 1986. Palynological and iridium anomalies at Cretaceous-Tertiary boundary, south-central Saskatchewan. Science 231:714-717.

Oksanen, J., F. G. Blanchet, M. Friendly, R. Kindt, P. Legendre, D. McGlinn, P. R. Minchin, R. B. O'Hara, G. L. Simpson, P. H. Solymos, M. H. Stevens, E. Szoecs, and H. Wagner. 2017. vegan: community ecology package. http://cran.r-project.org.

Orth, C. J., J. S. Gilmore, J. D. Knight, C. L. Pillmore, R. H. Tschudy, and J. E. Fassett. 1981. An iridium abundance anomaly at the palynological Cretaceous-Tertiary boundary in northern New Mexico. Science 214:1341-1343.

Palazzesi, L., and V. Barreda. 2007. Major vegetation trends in the Tertiary of Patagonia (Argentina): a qualitative paleoclimatic approach based on palynological evidence. Flora 202:328-337. 
Paradis, E., and K. Schliep. 2018. ape 5.0: an environment for modern phylogenetics and evolutionary analyses in R. Bioinformatics 35:526-528.

Pascual, R., M. Archer, E. Ortiz Jaureguizar, J. L. Prado, H. Godthelp, and S. Hand. 1992. First discovery of monotremes in South America. Nature 356:704-706.

Petriella, B., and S. Archangelsky. 1975. Vegetación y ambientes en el Paleoceno de Chubut. Actas del Primer Congreso Argentino de Paleontología y Bioestratigrafía 1:257-270. San Miguel de Tucumán, Argentina.

Pole, M., and V. Vajda. 2009. A new terrestrial Cretaceous-Paleogene site in New Zealand-turnover in macroflora confirmed by palynology. Cretaceous Research 30:917-938.

Prinn, R. G., and B. Fegley Jr. 1987. Bolide impacts, acid rain, and biospheric traumas at the Cretaceous-Tertiary boundary. Earth and Planetary Science Letters 83:1-15.

Quiroga, M. P., P. Mathiasen, A. Iglesias, R. R. Mill, and A. C. Premoli. 2015. Molecular and fossil evidence disentangle the biogeographical history of Podocarpus, a key genus in plant geography. Journal of Biogeography 43:372-383.

Raigemborn, M., M. Brea, A. Zucol, and S. Matheos. 2009. Early Paleogene climate at mid latitude in South America: mineralogical and paleobotanical proxies from continental sequences in Golfo San Jorge basin (Patagonia, Argentina). Geologica Acta 7:125-145.

Raigemborn, M. S., J. M. Krause, E. S. Bellosi, and S. D. Matheos. 2010. Redefinición estratigráfica del grupo Río Chico (Paleógeno Inferior), en el norte de la cuenca del Golfo de San Jorge, Chubut. Revista de la Asociación Geológica Argentina 67:239-256.

Raup, D. M., and J. J. Sepkoski. 1982. Mass extinctions in the fossil record. Science 215:1501-1503.

Robertson, D. S., W. M. Lewis, P. M. Sheehan, and O. B. Toon. 2013. K-Pg extinction patterns in marine and freshwater environments: the impact winter model. Journal of Geophysical Research: Biogeosciences 118:1006-1014.

Roy, K., and M. Foote. 1997. Morphological approaches to measuring biodiversity. Trends in Ecology and Evolution 12:277-281.

Ruiz, D. P., M. Brea, M. S. Raigemborn, and S. D. Matheos. 2017. Conifer woods from the Salamanca Formation (early Paleocene), central Patagonia, Argentina: paleoenvironmental implications. Journal of South American Earth Sciences 76:427-445.

Ruiz, D. P., M. S. Raigemborn, M. Brea, and R. R. Pujana. 2020. Paleocene Las Violetas fossil forest: wood anatomy and paleoclimatology. Journal of South American Earth Sciences 98:102414

Sauquet, H., and S. Magallón. 2018. Key questions and challenges in angiosperm macroevolution. New Phytologist 219:1170-1187.

Scasso, R. A., M. Aberhan, L. Ruiz, S. Weidemeyer, F. A. Medina, and W. Kiessling. 2012. Integrated bio- and lithofacies analysis of coarse-grained, tide-dominated deltaic environments across the Cretaceous/Paleogene boundary in Patagonia, Argentina. Cretaceous Research 36:37-57.

Scasso, R. A., M. B. Prámparo, J. Vellekoop, C. Franzosi, L. N. Castro, and J. S. Sinninghe Damsté. 2020. A high-resolution record of environmental changes from a Cretaceous-Paleogene section of Seymour Island, Antarctica. Palaeogeography, Palaeoclimatology, Palaeoecology 555:e109844.

Schueth, J. D., T. J. Bralower, S. Jiang, and M. E. Patzkowsky. 2015. The role of regional survivor incumbency in the evolutionary recovery of calcareous nannoplankton from the Cretaceous/ Paleogene (K/Pg) mass extinction. Paleobiology 41:661-679.

Schulte, P., L. Alegret, I. Arenillas, J. A. Arz, P. J. Barton, P. R. Bown, T. J. Bralower, G. L. Christeson, P. Claeys, C. S. Cockell, G. S. Collins, A. Deutsch, T. J. Goldin, K. Goto, J. M. Grajales-Nishimura, R. A. F. Grieve, S. P. S. Gulick, K. R. Johnson, W. Kiessling, C. Koeberl, D. A. Kring, K. G. MacLeod, T. Matsui, J. Melosh, A. Montanari, J. V. Morgan, C. R. Neal, D. J. Nichols, R. D. Norris, E. Pierazzo, G. Ravizza,
M. Rebolledo-Vieyra, W. U. Reimold, E. Robin, T. Salge, R. P. Speijer, A. R. Sweet, J. Urrutia-Fucugauchi, V. Vajda, M. T. Whalen, and P. S. Willumsen. 2010. The Chicxulub asteroid impact and mass extinction at the Cretaceous-Paleogene boundary. Science 327:1214-1218.

Schultz, P. H., and S. L. D'Hondt. 1996. The Chicxulub impact angle and its consequences. Geology 24:963-967.

Spalletti, L. A. 1996. Estuarine and shallow-marine sedimentation in the Upper Cretaceous-Lower Tertiary west-central Patagonian Basin (Argentina). Geological Society of America Special Publications 117:81-93.

Sterli, J., and M. S. de la Fuente. 2019. Cranial and post-cranial remains and phylogenetic relationships of the Gondwanan meiolaniform turtle Peligrochelys walshae from the Paleocene of Chubut, Argentina. Journal of Paleontology 93:798-821.

Stott, L. D., J. P. Kennett, N. J. Shackleton, and R. M. Corfield. 1990. The evolution of Antarctic surface waters during the Paleogene: inferences from the stable isotopic composition of planktonic foraminifers, ODP leg 1131. Proceedings of the Ocean Drilling Program, Scientific Results 113:849-863.

Sweet, A. R., and D. R. Braman. 2001. Cretaceous-Tertiary palynofloral perturbations and extinctions within the Aquilapollenites phytogeographic province. Canadian Journal of Earth Sciences 38:249-269.

Sweet, A. R., D. R. Braman, and J. F. Lerbekmo. 1990. Palynofloral response to $\mathrm{K} / \mathrm{T}$ boundary events: a transitory interruption within a dynamic system. Geological Society of America Special Paper 247:457-469

Sweet, A. R., D. R. Braman, and J. F. Lerbekmo. 1999. Sequential palynological changes across the composite Cretaceous-Tertiary (K-T) boundary claystone and contiguous strata, western Canada and Montana, U.S.A. Canadian Journal of Earth Sciences 36:743767.

Sylwan, C. A. 2001. Geology of the Golfo San Jorge Basin, Argentina. Journal of Iberian Geology 27:123-157.

Tabor, C. R., C. G. Bardeen, B. L. Otto-Bliesner, R. R. Garcia, and O. B. Toon. 2020. Causes and climatic consequences of the impact winter at the Cretaceous-Paleogene boundary. Geophysical Research Letters 47:e60121

Tipper, J. C. 1979. Rarefaction and rarefiction - the use and abuse of a method. Paleobiology 5:423-434.

Tyrrell, T., A. Merico, and D. I. Armstrong McKay. 2015. Severity of ocean acidification following the end-Cretaceous asteroid impact. Proceedings of the National Academy of Sciences USA 112:6556-6561.

Upchurch, G. R. J. 1995. Dispersed angiosperm cuticles: their history, preparation, and application to the rise of angiosperms in Cretaceous and Paleocene coals, southern western interior of North America. International Journal of Coal Geology 28:161-227.

Vajda, V., and A. Bercovici. 2014. The global vegetation pattern across the Cretaceous-Paleogene mass extinction interval: a template for other extinction events. Global and Planetary Change 122:29-49.

Vajda, V., and J. I. Raine. 2003. Pollen and spores in marine Cretaceous/Tertiary boundary sediments at mid-Waipara River, North Canterbury, New Zealand. New Zealand Journal of Geology and Geophysics 46:255-273.

Vajda, V., J. I. Raine, and C. J. Hollis. 2001. Indication of global deforestation at the Cretaceous-Tertiary boundary by New Zealand fern spike. Science 294:1700-1702.

Vajda-Santivanez, V. 1999. Miospores from upper CretaceousPaleocene strata in northwestern Bolivia. Palynology 23:181-196. Vellekoop, J., A. Sluijs, J. Smit, S. Schouten, J. W. H. Weijers, J. S. Sinninghe Damste, and H. Brinkhuis. 2014. Rapid short-term cooling following the Chicxulub impact at the Cretaceous-Paleogene boundary. Proceedings of the National Academy of Sciences USA 111:7537-7541. 
Vellekoop, J., F. Holwerda, M. B. Prámparo, V. Willmott, S. Schouten, N. R. Cúneo, R. A. Scasso, and H. Brinkhuis. 2017. Climate and sea-level changes across a shallow marine Cretaceous-Palaeogene boundary succession in Patagonia, Argentina. Palaeontology 60:519-534.

Volkheimer, W., L. Scafati, and D. L. Melendi. 2007. Palynology of a Danian warm climatic wetland in central northern Patagonia, Argentina. Revista Española de Micropaleontología 39:117-134.

Wilf, P. 1997. When are leaves good thermometers? A new case for leaf margin analysis. Paleobiology 23:373-390.

Wilf, P., and K. R. Johnson. 2004. Land plant extinction at the end of the Cretaceous: a quantitative analysis of the North Dakota megafloral record. Paleobiology 30:347-368.

Wilf, P., N. R. Cúneo, K. R. Johnson, J. F. Hicks, S. L. Wing, and J. D. Obradovich. 2003a. High plant diversity in Eocene South America: evidence from Patagonia. Science 300:122-125.

Wilf, P., K. R. Johnson, and B. T. Huber. 2003b. Correlated terrestrial and marine evidence for global climate changes before mass extinction at the Cretaceous-Paleogene boundary. Proceedings of the National Academy of Sciences USA 100:599-604.

Wilf, P., K. R. Johnson, N. R. Cúneo, M. E. Smith, B. S. Singer, and M. A. Gandolfo. 2005. Eocene plant diversity at Laguna del Hunco and Río Pichileufú, Patagonia, Argentina. American Naturalist 165:634-650.

Wilf, P., M. P. Donovan, N. R. Cúneo, and M. A. Gandolfo. 2017. The fossil flip-leaves (Retrophyllum, Podocarpaceae) of southern South America. American Journal of Botany 104:1344-1369.
Wills, M. A., D. E. G. Briggs, and R. A. Fortey. 1994. Disparity as an evolutionary index: a comparison of Cambrian and recent arthropods. Paleobiology 20:93-130.

Woelders, L., J. Vellekoop, D. Kroon, J. Smith, S. Casadío, M. B. Prámparo, J. Dinares-Turell, F. Peterse, A. Sluijs, J. T. Lenaerts, and R. P. Speijer. 2017. Latest Cretaceous climatic and environmental change in the South Atlantic region. Paleoceanography 32:466-483.

Wolfe, J. A. 1971. Tertiary climatic fluctuations and methods of analysis of Tertiary floras. Palaeogeography, Palaeoclimatology, Palaeoecology 9:27-57.

Wolfe, J. A. 1987. Late Cretaceous-Cenozoic history of deciduousness and the terminal Cretaceous event. Paleobiology 13:215-226.

Wolfe, J. A. 1995. Paleoclimatic estimates from Tertiary leaf assemblages. Annual Review of Earth and Planetary Sciences 23:119142.

Wolfe, J. A., and G. R. Upchurch. 1986. Vegetation, climatic and floral changes at the Cretaceous-Tertiary boundary. Nature 324:148-152.

Zamaloa, M. del C., and R. Andreis. 1995. Asociación palinológica del Paleoceno Temprano (Formación Salamanca) en Ea. Laguna Manantiales, Santa Cruz, Argentina. VI Congreso Argentino de Paleontología y Bioestratigrafía 1:301-305. Trelew, Argentina.

Zamuner, A., M. Brea, D. Ganuza, and S. Matheos. 2000. Resultados anatómico-sistemáticos preliminares en la lignoflora del Bosque de Szlápelis (Terciario Inferior), Provincia del Chubut, Argentina. Ameghiniana, Suplemento Resúmenes 37:80R. 